\title{
Experimental and Thermodynamic Assessment of the Nb-Ni-Y System
}

\author{
N. Mattern, M. Zinkevich, W. Löser, G. Behr, and J. Acker
}

(Submitted February 20, 2007; in revised form October 15, 2007)

\begin{abstract}
Phase equilibria in the ternary Nb-Ni-Y system are studied experimentally for the first time using $x$-ray diffraction, electron probe microanalysis, and differential scanning calorimetry in combination with levitation experiments. No ternary compounds exist, while the solubility of third element in binary solid phases is negligible. A subsolidus isothermal section at $750{ }^{\circ} \mathrm{C}$, fields of primary crystallization, invariant reactions, as well as an extension of the liquid miscibility gap from the Nb-Y binary system are determined. Thermodynamic model description for the $\mathrm{Nb}$-Ni-Y system including the binary $\mathrm{Nb}-\mathrm{Y}$ subsystem is developed and used for calculations of the projection of liquidus surface, isothermal, and vertical sections.
\end{abstract}

Keywords nickel, niobium, phase equilibria, phase separation, thermodynamics, yttrium

\section{Introduction}

Phase separation in bulk metallic glasses has now attracted considerable interest because the introduction of suitable inhomogeneities is an important concept to improve the mechanical properties, especially to increase the ductility. ${ }^{[1]}$ The amorphous structure formation in these novel metallic materials is achieved by rapid quenching of the melt; however, they exhibit nanoscale composition inhomogeneities, which are "frozen in" into a two-phase amorphous alloy. This interesting behavior has already been demonstrated for a five-component $\mathrm{Zr}-\mathrm{Y}-\mathrm{Ni}-\mathrm{Cu}-\mathrm{Al}$ alloy ${ }^{[2]}$ and a quaternary Co-Al-Ni-Y alloy. ${ }^{[3]}$ Only recently have phase separated metallic glasses of a ternary system $\mathrm{Nb}-\mathrm{Ni}$ $\mathrm{Y}$ been prepared by rapid quenching from the melt. ${ }^{[4]}$

Generally, alloys for new phase-separated metallic glasses are designed by combining elements with high glass-forming ability with an element having strong tendency to demix at least for one of the other main constituents. The rapid solidification of such alloys leads to special hierarchical microstructures. The understanding of microstructure formation is rather poor and requires the knowledge of the thermodynamic data of the alloy systems, which are practically unknown until now. So far, the ternary $\mathrm{Nb}-\mathrm{Ni}-\mathrm{Y}$ system is the simplest system of this type and

N. Mattern, W. Löser, and G. Behr, Leibniz-Institut für Festkörperund Werkstoffforschung IFW Dresden, Helmholtzstraße 20, D-01069 Dresden, Germany; M. Zinkevich, Max Planck Institut für Metallforschung, Heisenbergstraße 3, D-70569 Stuttgart, Germany; J. Acker, Leibniz-Institut für Festkörper- und Werkstoffforschung IFW Dresden, Helmholtzstraße 20, D-01069 Dresden, Germany; and J. Acker, Fachhochschule Lausitz, Großenhainer Straße 57, D-01968 Senftenberg, Germany. Contact e-mail: N.Mattern@ifw-dresden.de.

offers the unique possibility for thermodynamic calculations as a basis for understanding the formation of phaseseparated metallic glasses. Therefore, in this paper the $\mathrm{Nb}$ $\mathrm{Ni}-\mathrm{Y}$ phase diagram is experimentally as well as thermodynamically assessed. The CALPHAD method ${ }^{[5]}$ is best suited for this purpose, since it allows easy calculation of unknown phase equilibria in multicomponent systems based on the Gibbs energies of constituent phases in the lowerorder binary and ternary systems, in terms of known thermodynamic and phase equilibria data.

\section{Sample Preparation and Methods of Investigation}

Ingots of the alloys were melted from $99.9 \mathrm{wt} . \% \mathrm{Nb}$ and 99.99 wt.\% Ni and Y (Alfa Aesar) in an argon arc furnace, using a nonconsumable tungsten electrode on a watercooled copper hearth. The alloys were remelted four times; the ingot was inverted after each melt to promote mixing. The mass of each ingot was about $30 \mathrm{~g}$. The ingots were wrapped in tantalum foil, annealed at 750 to $1000{ }^{\circ} \mathrm{C}$ for $24 \mathrm{~h}$ in sealed silica ampoules under $15 \mathrm{kPa}$ purified $\mathrm{Ar}$ gas and then quenched into water. Specimens of a selected composition (about $2 \mathrm{~g}$ ) were heated in a levitation apparatus under high-purity argon atmosphere to temperatures above the liquidus. Temperature was measured by a pyrometer. By switching off the levitation field, the melt became rapidly quenched on a copper plate.

Three exact weights per samples close to $50 \mathrm{mg}$ were dissolved in $5 \mathrm{~mL}$ concentrated hydrochloric acid (Merck, p.a.) at $180{ }^{\circ} \mathrm{C}$ for $15 \mathrm{~min}$ by microwave digestion ( $\mu$ Prep, MWS) using $100 \mathrm{~mL}$ Teflon vessels. The diluted sample solutions were prepared by weighing and were adjusted to a total hydrochloric acid concentration of $5 \mathrm{wt} . \%$. Chemical analysis was performed by inductively coupled plasma optical emission spectrometry (ICP-OES) by a radial IRIS Intrepid II XUV (Thermo Corp., Franklin, MA) with an Echelle optics, a charge injection device (CID) detector for 
simultaneous recording of the selected emission lines, and a cyclonic glass spray chamber with SeaSpray nebulizer. The analytical results are obtained from the background corrected emission intensities of at least three different emission lines of each element. All measurements were performed in the so-called bracketing mode by placing a sample between two standards to compensate for timedependent drift effects. Each sample was measured in three different runs to improve the statistical significance. This procedure yields typical uncertainties in the element contents of $0.5 \% \operatorname{RSD}(1 \sigma)$ and below.

$\mathrm{X}$-ray diffraction analysis (XRD) was conducted with a Panalytical XPERT'Pro Bragg-Brentano diffractometer (PANALYTICAL, Almelo, The Netherlands) using Co $\mathrm{K} \alpha$ radiation and a diffracted beam graphite monochromator. Powders with a particle size of $\leq 100 \mu \mathrm{m}$ were prepared from ingots using a hard metal mortar and pestle as well as a sieve. X-ray diffraction patterns $I(2 \theta)$ were recorded for $2 \theta$ values from $20.0^{\circ}$ to $120^{\circ}$ with a step size of $0.05^{\circ}$, and a measuring time of $5 \mathrm{~s}$ per step. For qualitative and quantitative phase analysis, the whole pattern Rietveld method was applied.

All samples were prepared for metallographic examination by polishing the resin-mounted specimens with diamond pastes. The microstructure was analyzed by scanning electron microscopy (SEM) in the backscattered electron (BSE) imaging mode using a Philips XL30 (PHILIPS, Eindhoven, The Netherlands). The chemical composition of the individual phases was measured by electron probe $\mathrm{x}$-ray microanalysis (EPMA) using wavelength-dispersive $\mathrm{x}$-ray (WDX) spectroscopy for determination of solubilities as well as energy-dispersive (EDX) for chemical phase characterization. Binary $\mathrm{Ni}-\mathrm{Nb}$ and $\mathrm{Ni}-\mathrm{Y}$ alloys were used as standard materials. The characteristic wavelengths of $\mathrm{Nb} \mathrm{L} \alpha, \mathrm{Ni} \mathrm{K} \alpha$, and Y L $\alpha$ were detected to determine the concentration of the elements using an acceleration voltage of $20 \mathrm{kV}$. The area of the analyzing window on the specimen surface was between 1 by $1 \mu \mathrm{m}$ and 50 by $50 \mu \mathrm{m}$, depending on the microstructure. The standard deviations of the element concentration were calculated from three to five independent measurements, moving the electron probe each time to a new position.

Differential scanning calorimetry (DSC) studies of the annealed samples were done using a Netzsch DSC 404 (NETZSCH, Selb, Germany) at a heating rate of $20 \mathrm{~K} / \mathrm{min}$ up to 1400 to $1500{ }^{\circ} \mathrm{C}$ in an argon atmosphere.

\section{Thermodynamic Modeling}

The Gibbs energy of each element is defined with respect to its stable magnetically disordered state at $298.15 \mathrm{~K}$ and $10^{5} \mathrm{~Pa}$ (stable element reference). In the SGTE-Pure database, ${ }^{[6]}$ the Gibbs energy is represented as a power series in terms of temperature in the form:

${ }^{\circ} G(T)=a+b T+c T \ln (T)+d T^{2}+e T^{3}+f / T+\sum_{n} g_{n} T^{n}$

where $a$ to $f$ and $g_{n}$ are coefficients and $n$ represents a set of integers. The reference states for the pure niobium, nickel,
Table 1 Summary of thermodynamic parameters describing the $\mathrm{Nb}-\mathrm{Ni}-\mathrm{Y}$ system referred to the stable element reference $H^{\text {SER }}(T=298.15 \mathrm{~K}, P=100 \mathrm{kPa})$. Values are given in SI units (J, mol, and $K)$, except $\beta$ ( $\mu_{B}$ per mole of atoms)

\begin{tabular}{|c|c|}
\hline Parameter & Ref \\
\hline$G_{\mathrm{Nb}}^{\mathrm{bcc}}, G_{\mathrm{Nb}}^{\mathrm{fcc}}, G_{\mathrm{Nb}}^{\mathrm{cph}}, G_{\mathrm{Nb}}^{\mathrm{liq}}, G_{\mathrm{Ni}}^{\mathrm{bcc}}, G_{\mathrm{Ni}}^{\mathrm{fcc}}, G_{\mathrm{Ni}}^{\mathrm{cph}}, G_{\mathrm{Ni}}^{\mathrm{liq}}, G_{\mathrm{Y}}^{\mathrm{bcc}}, G_{\mathrm{Y}}^{\mathrm{fcc}}, G_{\mathrm{Y}}^{\mathrm{hcp}}, G_{\mathrm{Y}}^{\mathrm{liq}}$ & 6 \\
\hline${ }^{0} L_{\mathrm{Nb}, \mathrm{Ni}}^{\mathrm{liq}}=-96,160+22 T$ & 8 \\
\hline${ }^{1} L_{\mathrm{Nb}, \mathrm{Ni}}^{\mathrm{liq}}=104,000-45 T$ & 8 \\
\hline${ }^{0} L_{\mathrm{Ni}, \mathrm{Y}}^{\mathrm{Niq}, \mathrm{N1}}=-15,5496+38.932 T$ & 8 \\
\hline${ }^{1} L_{\mathrm{Ni}, \mathrm{Y}}^{\mathrm{liq}, \mathrm{I}}=-52,904+6.785 T$ & 8 \\
\hline${ }^{0} L_{\mathrm{Nb}, \mathrm{Y}}^{\mathrm{liq}, \mathrm{Y}}=+188,000-61.3 T$ & This work \\
\hline${ }^{1} L_{\mathrm{Nb}, \mathrm{Y}}^{\text {liq }}=+39,500$ & This work \\
\hline${ }^{0} L_{\mathrm{Nb}, \mathrm{Ni}, \mathrm{Y}}^{\mathrm{liq}, 1}=+33,700$ & This work \\
\hline${ }^{1} L_{\mathrm{Nb}, \mathrm{Ni}, \mathrm{Y}}^{\mathrm{li}, \mathrm{N}, \mathrm{Y}}=-22,800$ & This work \\
\hline${ }^{2} L_{\mathrm{Nb}, \mathrm{Ni}, \mathrm{Y}}^{\mathrm{liq}}=+184,350$ & This work \\
\hline${ }^{0} L_{\mathrm{Nb}, \mathrm{Ni}}^{\mathrm{fcc}}=-110,300+39.5 T$ & 8 \\
\hline${ }^{1} L_{\mathrm{Nb}, \mathrm{Ni}}^{\mathrm{fcc}}=+40,000$ & 8 \\
\hline${ }^{0} L_{\mathrm{Ni}, \mathrm{Y}}^{\mathrm{fcc}, \mathrm{N}_{1}}=-2,000$ & 15 \\
\hline${ }^{0} L_{\mathrm{Nb}, \mathrm{Y}}^{\mathrm{fcc}}=+100,000$ & This work \\
\hline$\left(T_{\mathrm{C}}\right)_{\mathrm{Ni}}^{\mathrm{fcc}}=633 ; \beta_{\mathrm{Ni}}^{\mathrm{fcc}}=0.52$ & 6 \\
\hline${ }^{0}\left(T_{\mathrm{C}}\right)_{\mathrm{Nb}, \mathrm{Ni}}^{\mathrm{fcc}}=-2,500 ;{ }^{0} \beta_{\mathrm{Nb}, \mathrm{Ni}}^{\mathrm{fcc}}=0$ & 8 \\
\hline${ }^{0} L_{\mathrm{Nb}, \mathrm{Ni}}^{\mathrm{bcc}}=-28,000+20 T$ & 8 \\
\hline${ }^{0} L_{\mathrm{Ni}, \mathrm{Y}}^{\mathrm{bcc}}=-2,000$ & 15 \\
\hline${ }^{0} L_{\mathrm{Nb}, \mathrm{Y}}^{\mathrm{bcc}}=+150,000$ & This work \\
\hline$\left(T_{\mathrm{C}}\right)_{\mathrm{Ni}}^{\mathrm{bcc}}=575 ; \beta_{\mathrm{Ni}}^{\mathrm{bcc}}=0.85$ & 6 \\
\hline${ }^{0} L_{\mathrm{Nb}, \mathrm{Ni}}^{\mathrm{cph}}=+150,000$ & This work \\
\hline${ }^{0} L_{\mathrm{Ni}, \mathrm{Y}}^{\mathrm{cph}}=-2,000$ & 15 \\
\hline${ }^{0} L_{\mathrm{Nb}, \mathrm{Y}}^{\mathrm{cph}}=+150,000$ & This work \\
\hline$G_{\mathrm{Nb}: \mathrm{Ni}}^{\mathrm{NbN}}=-145,000+46 T+G_{\mathrm{Nb}}^{\mathrm{bcc}}+8 G_{\mathrm{Ni}}^{\mathrm{fcc}}$ & 8 \\
\hline$G_{\mathrm{Nb}: \mathrm{Ni}}^{\mathrm{NbN} i}=-128,100+33 T+G_{\mathrm{Nb}}^{\mathrm{bcc}}+3 G_{\mathrm{Ni}}^{\mathrm{fic}}$ & 8 \\
\hline$G_{\mathrm{Ni} \mathrm{Nb}}^{\mathrm{NbNi_{3 }}}=+168,100-33 T+3 G_{\mathrm{Nb}}^{\mathrm{bcc}}+G_{\mathrm{Ni}}^{\mathrm{fcc}}$ & 8 \\
\hline$G_{\mathrm{Nb}: \mathrm{Nb}}^{\mathrm{Nb} \mathrm{Ni}_{3}}=+20,000+4 G_{\mathrm{Nb}}^{\mathrm{bcc}}$ & 8 \\
\hline$G_{\mathrm{Ni}: \mathrm{Ni}}^{\mathrm{NbNi}}=+20,000+4 G_{\mathrm{Ni}}^{f c c}$ & 8 \\
\hline$G_{*: \mathrm{Nb}, \mathrm{Ni}}^{\mathrm{NbN}}=+100,000$ & 8 \\
\hline$G_{\mathrm{Nb}, \mathrm{Ni}: *}^{\mathrm{NbNi}}=0$ & 8 \\
\hline$G_{\mathrm{Nb}: \mathrm{Nb}: \mathrm{Nb}: \mathrm{Nb}: \mathrm{Ni}}^{\mathrm{\mu}}=-279,000+58 T+7 G_{\mathrm{Nb}}^{\mathrm{bcc}}+6 G_{\mathrm{Ni}}^{\mathrm{fcc}}$ & 8 \\
\hline$G_{\mathrm{Ni}: \mathrm{Nb}: \mathrm{Nb}: \mathrm{Nb}: \mathrm{Ni}}^{\mathrm{\mu}}=-285,000+58 T+6 G_{\mathrm{Nb}}^{\mathrm{bu}}+7 G_{\mathrm{Ni}}^{\mathrm{fec}}$ & 8 \\
\hline$G_{\mathrm{Ni}: \mathrm{Nb}: \mathrm{Nb}: \mathrm{Ni}: \mathrm{Ni}}^{\mu}=-296,000+58 T+4 G_{\mathrm{Nb}}^{\mathrm{bcc}}+9 G_{\mathrm{Ni}}^{\mathrm{fcc}}$ & 8 \\
\hline$G_{\mathrm{Nb}: \mathrm{Nb}: \mathrm{Nb}: \mathrm{Nb}: \mathrm{Nb}}^{\mathrm{\mu}}=+130,000+13 G_{\mathrm{Nb}}^{\mathrm{bcc}}$ & 8 \\
\hline$G_{\mathrm{Ni}: \mathrm{Nb}: \mathrm{Nb}: \mathrm{Nb}: \mathrm{Nb}}^{\mathrm{\mu}}=+130,000+12 G_{\mathrm{Nb}}^{\mathrm{bcc}}+G_{\mathrm{Ni}}^{\mathrm{fcc}}$ & 8 \\
\hline$G_{\mathrm{Nb}: \mathrm{Nb}: \mathrm{Nb}: \mathrm{Ni}: \mathrm{Nb}}^{\mathrm{\mu}}=+130,000+11 G_{\mathrm{Nb}}^{\mathrm{bcc}}+2 G_{\mathrm{Ni}}^{\mathrm{fcc}}$ & 8 \\
\hline$G_{\mathrm{Ni}: \mathrm{Nb}: \mathrm{Nb}: \mathrm{Ni}: \mathrm{Nb}}^{\mu}=+130,000+10 G_{\mathrm{Nb}}^{\mathrm{bcc}}+3 G_{\mathrm{Ni}}^{\mathrm{fcc}}$ & 8 \\
\hline$G_{\mathrm{Nb}: \mathrm{Nb}: \mathrm{Nb}: \mathrm{Ni}: \mathrm{Ni}}^{\mu}=-290,000+58 T+5 G_{\mathrm{Nb}}^{\mathrm{bcc}}+8 G_{\mathrm{Ni}}^{\mathrm{fcc}}$ & 8 \\
\hline$G^{\mathrm{Ni}_{17} \mathrm{Y}} \mathrm{Y}_{2}=-379,600+57.635 T+17 G_{\mathrm{Ni}}^{\mathrm{fcc}}+2 G_{\mathrm{Y}}^{\mathrm{cph}}$ & This work \\
\hline$G^{\mathrm{Ni}_{5} \mathrm{Y}}=-186,706+31.187 T+5 G_{\mathrm{Ni}}^{\mathrm{fcc}}+G_{\mathrm{Y}}^{\mathrm{cph}}$ & 15 \\
\hline$G^{\mathrm{Ni}_{4} \mathrm{Y}}=-160,555+22.979 T+4 G_{\mathrm{Ni}}^{\mathrm{fcc}}+G_{\mathrm{Y}}^{\mathrm{cph}}$ & 15 \\
\hline$G^{\mathrm{Ni}_{7} \mathrm{Y}_{2}}=-294,966+38.770 T+7 G_{\mathrm{Ni}}^{\mathrm{fcc}}+2 G_{\mathrm{Y}}^{\mathrm{cph}}$ & 15 \\
\hline$G^{\mathrm{Ni}_{3} \mathrm{Y}}=-134,358+16.477 T+3 G_{\mathrm{Ni}}^{\mathrm{fcc}}+G_{\mathrm{Y}}^{\mathrm{cph}}$ & 15 \\
\hline$G^{\mathrm{Ni}_{2} \mathrm{Y}}=-101,736+8.988 T+2 G_{\mathrm{Ni}}^{\mathrm{fcc}}+G_{\mathrm{Y}}^{\mathrm{ph}}$ & 15 \\
\hline$G^{\mathrm{NiY}}=-67,151.8+5.5642 T+G_{\mathrm{Ni}}^{\mathrm{ccc}}+G_{\mathrm{Y}}^{\mathrm{cph}}$ & 15 \\
\hline$G^{\mathrm{Ni}_{2} \mathrm{Y}_{3}}=-162,837.5+32.5369 T+2 G_{\mathrm{Ni}}^{\mathrm{fcc}}+3 G_{\mathrm{Y}}^{\mathrm{cph}}$ & 15 \\
\hline$G^{\mathrm{NiY}_{3}}=-84,446+14.1911 T+G_{\mathrm{Ni}}^{\mathrm{fcc}}+3 G_{\mathrm{Y}}^{\mathrm{cph}}$ & 15 \\
\hline
\end{tabular}

and yttrium are: body-centered cubic (bcc) $\mathrm{Nb}$, a hypothetical magnetically disordered face-centered cubic (fcc) $\mathrm{Ni}$, and close-packed hexagonal (cph) Y, respectively. The 
corresponding coefficients for stable and metastable structures are taken from the compilation of Dinsdale. ${ }^{[6]}$ Equation 1 also applies for the stoichiometric compounds and end members of solutions. The ordered intermetallic phases with a homogeneity range are represented by sublattice models based on compound energy formalism ${ }^{[7]}$ as follows: ${ }^{[8]}(\mathrm{Nb}, \mathrm{Ni})(\mathrm{Nb})_{2}(\mathrm{Nb})_{2}(\mathrm{Nb}, \mathrm{Ni})_{2}(\mathrm{Nb}, \mathrm{Ni})_{6}$ for the $\mu$-phase, and $(\mathrm{Nb}, \mathrm{Ni})(\mathrm{Nb}, \mathrm{Ni})_{3}$ for the $\mathrm{NbNi}_{3}$-phase.

The liquid and disordered solid solutions, bcc, fcc, and cph are described using a substitutional solution model, the Gibbs energy being defined as:

$$
\begin{aligned}
G^{\phi} & =\sum_{i=1}^{3} x_{i} G_{i}^{\mathrm{ref}}+G^{\mathrm{id}}+G^{\mathrm{ex}} ; G^{\mathrm{id}}=R T \sum_{i=1}^{3} x_{i} \ln \left(x_{i}\right) \\
G^{\mathrm{ex}} & =\sum_{i=1}^{3} \sum_{j>i}^{3} x_{i} x_{j} \sum_{v=0}^{n}{ }^{v} L_{i, j}\left(x_{i}-x_{j}\right)^{v}+x_{i} x_{j} x_{k}{ }^{0} L_{i, j, k}
\end{aligned}
$$

where $G_{i}^{\text {ref }}$ is the reference Gibbs energy of the pure element $i$, that is, $\mathrm{Nb}, \mathrm{Ni}$, or $\mathrm{Y}$ in the corresponding form $\varphi ; G^{\text {id }}$ is the ideal mixing contribution; $G^{\mathrm{ex}}$ is the excess energy; $x_{i}$, $x_{j}$, and $x_{k}$ are the mole fractions of the constituents $i, j$, and $k$, respectively. ${ }^{v} L_{i, j}$ is the binary interaction parameter of

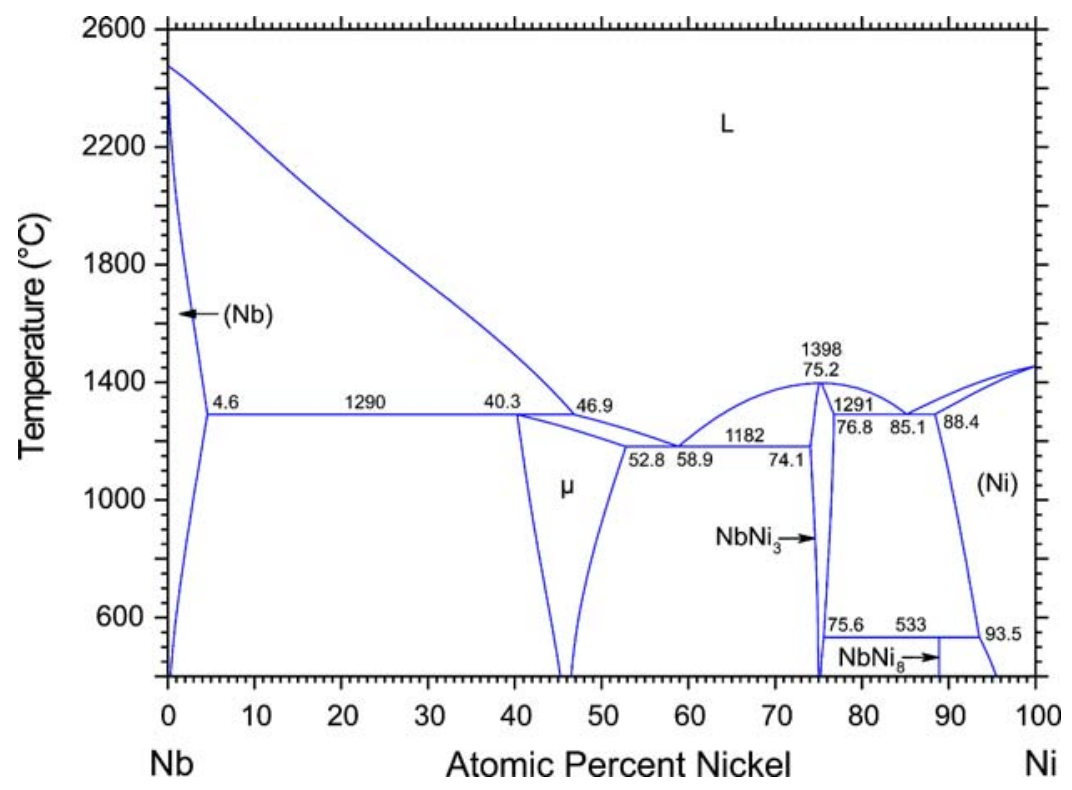

Fig. 1 Nb-Ni phase diagram calculated using the thermodynamic description from Ref 8

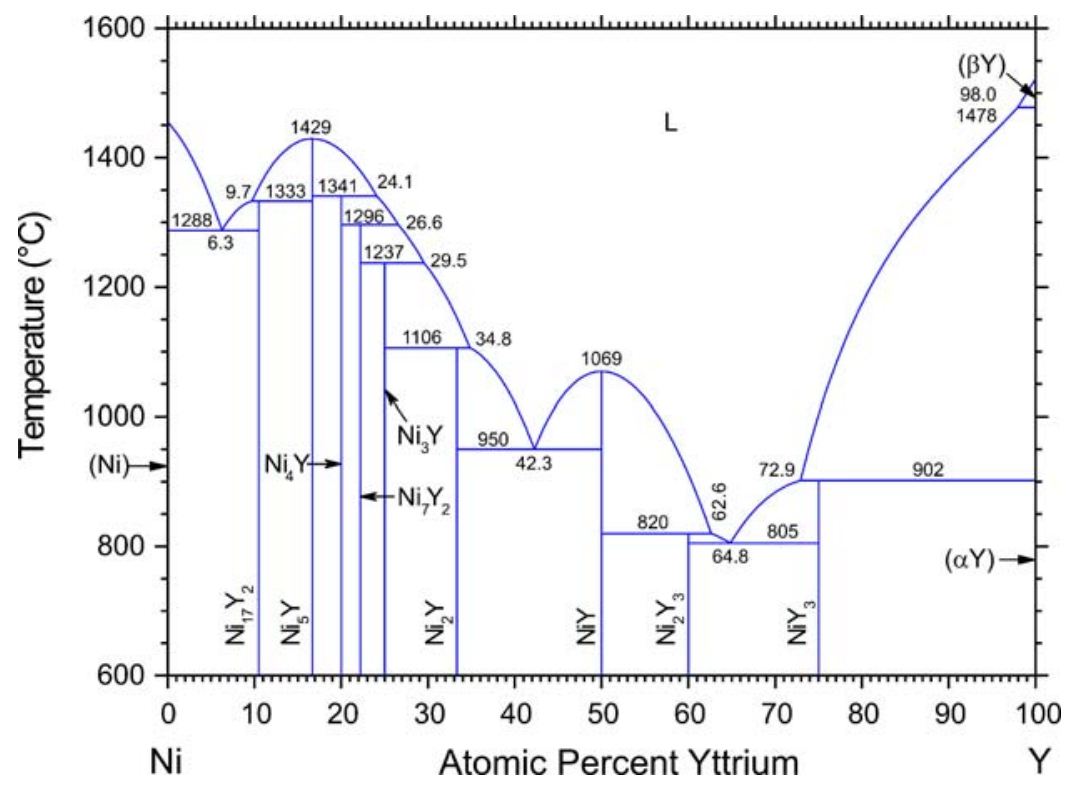

Fig. 2 Calculated Ni-Y phase diagram based on thermodynamic assessment from Ref 15 
components $i$ and $j$ of an order $\mathrm{v}$, and $L_{i, j, k}$ is the ternary interaction parameter. The latter has the following composition dependence:

$L_{\mathrm{Nb}, \mathrm{Ni}, \mathrm{Y}}=x_{\mathrm{Nb}}{ }^{0} L_{\mathrm{Nb}, \mathrm{Ni}, \mathrm{Y}}+x_{\mathrm{Ni}}{ }^{1} L_{\mathrm{Nb}, \mathrm{Ni}, \mathrm{Y}}+x_{\mathrm{Y}}{ }^{2} L_{\mathrm{Nb}, \mathrm{Ni}, \mathrm{Y}}$
Magnetic contributions into the Gibbs energy of fcc and bcc phases are taken into account according to the treatment proposed by Hillert and Jarl. ${ }^{[9]}$

The thermodynamic model parameters for the ternary system $\mathrm{Nb}-\mathrm{Ni}-\mathrm{Y}$ are evaluated on the basis of the experi-

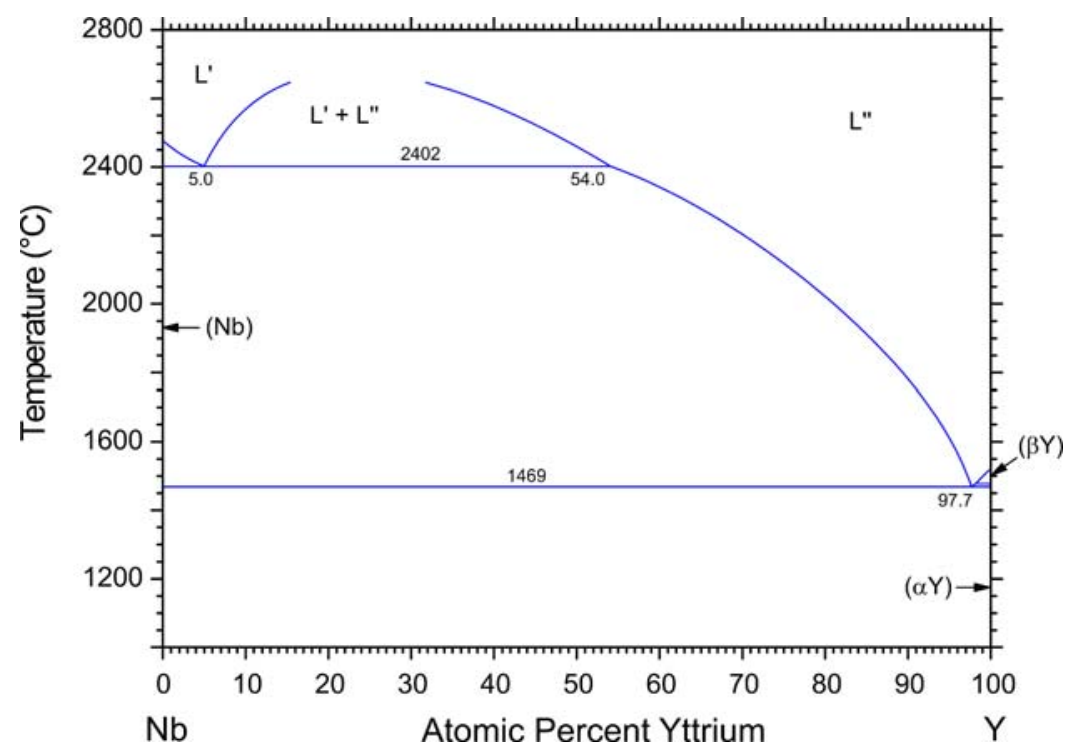

Fig. 3 The Nb-Y phase diagram optimized and calculated in this work

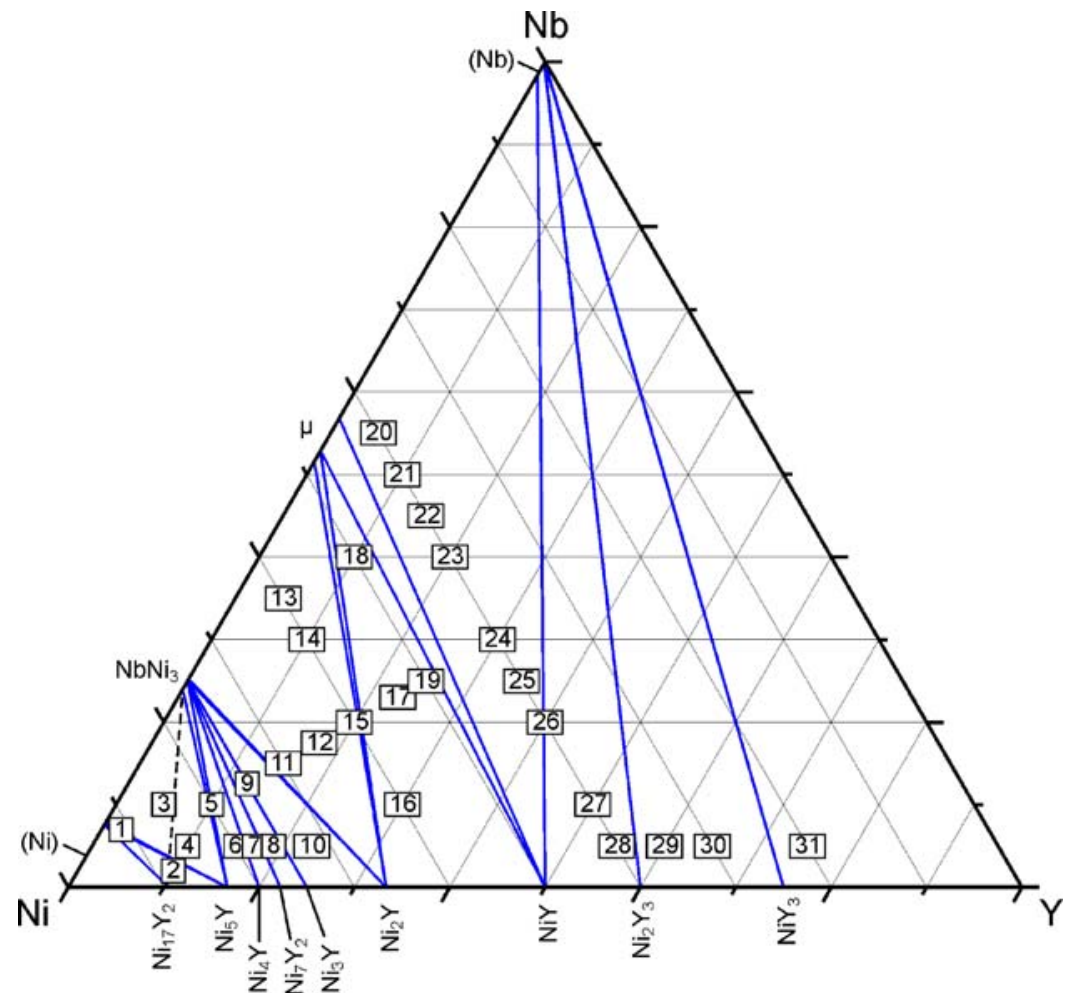

Fig. 4 Calculated isothermal section of the Nb-Ni-Y system at $750{ }^{\circ} \mathrm{C}$ in atomic percents. Squared numbers correspond to the investigated alloys (Table 2). Dashed line shows the $\mathrm{Ni}_{17} \mathrm{Y}_{2}-\mathrm{NbNi}_{3}$ equilibrium calculated with the initial thermodynamic parameters of $\mathrm{Ni}_{17} \mathrm{Y}_{2}$ phase from Ref 15 
Table 2 Results of phase analysis of ternary Nb-Ni-Y alloys annealed at $750{ }^{\circ} \mathrm{C}$ for $24 \mathrm{~h}$

\begin{tabular}{|c|c|c|c|c|}
\hline \multirow[b]{2}{*}{ No. } & \multicolumn{2}{|c|}{ Composition of alloy, at. $\%$} & \multirow[b]{2}{*}{ Phases observed by XRD } & \multirow[b]{2}{*}{ Phases observed by SEM/EDX } \\
\hline & Nominal & ICP-OES & & \\
\hline 1 & $\mathrm{Ni}_{91} \mathrm{Nb}_{7} \mathrm{Y}_{2}$ & $\mathrm{Ni}_{91.00} \mathrm{Nb}_{7.03} \mathrm{Y}_{1.97}$ & $(\mathrm{Ni})+\mathrm{Ni}_{17} \mathrm{Y}_{2}$ & $(\mathrm{Ni})+\mathrm{Ni}_{17} \mathrm{Y}_{2}$ \\
\hline 2 & $\mathrm{Ni}_{88} \mathrm{Nb}_{2} \mathrm{Y}_{10}$ & $\mathrm{Ni}_{88.35} \mathrm{Nb}_{2.04} \mathrm{Y}_{9.61}$ & $(\mathrm{Ni})+\mathrm{Ni}_{17} \mathrm{Y}_{2}+\mathrm{Ni}_{5} \mathrm{Y}$ & $(\mathrm{Ni})+\mathrm{Ni}_{5} \mathrm{Y}$ \\
\hline 3 & $\mathrm{Ni}_{85} \mathrm{Nb}_{10} \mathrm{Y}_{5}$ & $\mathrm{Ni}_{85.16} \mathrm{Nb}_{9.92} \mathrm{Y}_{4.92}$ & $(\mathrm{Ni})+\mathrm{Ni}_{5} \mathrm{Y}$ & $(\mathrm{Ni})+\mathrm{Ni}_{5} \mathrm{Y}+\mathrm{NbNi}_{3}$ \\
\hline 4 & $\mathrm{Ni}_{85} \mathrm{Nb}_{5} \mathrm{Y}_{10}$ & $\mathrm{Ni}_{85.29} \mathrm{Nb}_{5.02} \mathrm{Y}_{9.68}$ & $(\mathrm{Ni})+\mathrm{Ni}_{5} \mathrm{Y}+\mathrm{NbNi}_{3}$ & $(\mathrm{Ni})+\mathrm{Ni}_{5} \mathrm{Y}+\mathrm{NbNi}_{3}$ \\
\hline 5 & $\mathrm{Ni}_{80} \mathrm{Nb}_{10} \mathrm{Y}_{10}$ & $\mathrm{Ni}_{80.38} \mathrm{Nb}_{9.99} \mathrm{Y}_{9.63}$ & $\mathrm{Ni}_{5} \mathrm{Y}+\mathrm{NbNi}_{3}$ & $\mathrm{Ni}_{5} \mathrm{Y}+\mathrm{NbNi}_{3}$ \\
\hline 6 & $\mathrm{Ni}_{80} \mathrm{Nb}_{5} \mathrm{Y}_{15}$ & $\mathrm{Ni}_{80.46} \mathrm{Nb}_{4.97} \mathrm{Y}_{14.57}$ & $\mathrm{Ni}_{5} \mathrm{Y}+\mathrm{Ni}_{4} \mathrm{Y}+\mathrm{NbNi}_{3}$ & $\mathrm{Ni}_{5} \mathrm{Y}+\mathrm{Ni}_{4} \mathrm{Y}+\mathrm{NbNi}_{3}$ \\
\hline 7 & $\mathrm{Ni}_{78} \mathrm{Nb}_{5} \mathrm{Y}_{17}$ & $\mathrm{Ni}_{78.57} \mathrm{Nb}_{4.77} \mathrm{Y}_{16.66}$ & $\mathrm{Ni}_{5} \mathrm{Y}+\mathrm{Ni}_{4} \mathrm{Y}+\mathrm{NbNi}_{3}(\mathrm{a})$ & $\mathrm{Ni}_{5} \mathrm{Y}+\mathrm{Ni}_{4} \mathrm{Y}+\mathrm{NbNi}_{3}$ \\
\hline 8 & $\mathrm{Ni}_{76} \mathrm{Nb}_{5} \mathrm{Y}_{19}$ & $\mathrm{Ni}_{76.66} \mathrm{Nb}_{4.90} \mathrm{Y}_{18.44}$ & $\mathrm{Ni}_{3} \mathrm{Y}+\mathrm{Ni}_{7} \mathrm{Y}_{2}+\mathrm{NbNi}_{3}$ & $\mathrm{Ni}_{3} \mathrm{Y}+\mathrm{NbNi}_{3}$ \\
\hline 9 & $\mathrm{Ni}_{75} \mathrm{Nb}_{12.5} \mathrm{Y}_{12.5}$ & & $\mathrm{Ni}_{3} \mathrm{Y}+\mathrm{NbNi}_{3}$ & $\mathrm{Ni}_{3} \mathrm{Y}+\mathrm{NbNi}_{3}$ \\
\hline 10 & $\mathrm{Ni}_{72} \mathrm{Nb}_{5} \mathrm{Y}_{23}$ & $\mathrm{Ni}_{72.68} \mathrm{Nb}_{5.04} \mathrm{Y}_{22.28}$ & $\mathrm{Ni}_{3} \mathrm{Y}+\mathrm{Ni}_{2} \mathrm{Y}+\mathrm{NbNi}_{3}$ & $\mathrm{Ni}_{2} \mathrm{Y}+\mathrm{NbNi}_{3}$ \\
\hline 11 & $\mathrm{Ni}_{70} \mathrm{Nb}_{15} \mathrm{Y}_{15}$ & $\mathrm{Ni}_{71.77} \mathrm{Nb}_{13.2} \mathrm{Y}_{15.03}$ & $\mathrm{Ni}_{2} \mathrm{Y}+\mathrm{NbNi}_{3}$ & $\mathrm{Ni}_{2} \mathrm{Y}+\mathrm{NbNi}_{3}$ \\
\hline 12 & $\mathrm{Ni}_{65} \mathrm{Nb}_{17.5} \mathrm{Y}_{17.5}$ & & $\mathrm{Ni}_{2} \mathrm{Y}+\mathrm{NbNi}_{3}+\mu$ & \\
\hline 13 & $\mathrm{Ni}_{60} \mathrm{Nb}_{35} \mathrm{Y}_{5}$ & $\mathrm{Ni}_{60.21} \mathrm{Nb}_{34.93} \mathrm{Y}_{4.86}$ & $\mathrm{Ni}_{2} \mathrm{Y}+\mathrm{NbNi}_{3}+\mu$ & $\mathrm{Ni}_{2} \mathrm{Y}+\mathrm{NbNi}_{3}+\mu$ \\
\hline 14 & $\mathrm{Ni}_{60} \mathrm{Nb}_{30} \mathrm{Y}_{10}$ & $\mathrm{Ni}_{60.22} \mathrm{Nb}_{29.30} \mathrm{Y}_{10.47}$ & $\mathrm{Ni}_{2} \mathrm{Y}+\mathrm{NbNi}_{3}+\mu$ & \\
\hline 15 & $\mathrm{Ni}_{60} \mathrm{Nb}_{20} \mathrm{Y}_{20}$ & $\mathrm{Ni}_{60.80} \mathrm{Nb}_{19.59} \mathrm{Y}_{19.61}$ & $\mathrm{Ni}_{2} \mathrm{Y}+\mu$ & $\mathrm{Ni}_{2} \mathrm{Y}+\mu$ \\
\hline 16 & $\mathrm{Ni}_{60} \mathrm{Nb}_{10} \mathrm{Y}_{30}$ & $\mathrm{Ni}_{60.47} \mathrm{Nb}_{10.03} \mathrm{Y}_{29.50}$ & $\mathrm{Ni}_{2} \mathrm{Y}+\mathrm{NiY}+\mu$ & \\
\hline 17 & $\mathrm{Ni}_{54} \mathrm{Nb}_{23} \mathrm{Y}_{23}$ & $\mathrm{Ni}_{54.90} \mathrm{Nb}_{25.00} \mathrm{Y}_{20.10}$ & $\mathrm{Ni}_{2} \mathrm{Y}+\mathrm{NiY}+\mathrm{NbNi}_{3}$ & \\
\hline 18 & $\mathrm{Ni}_{50} \mathrm{Nb}_{40} \mathrm{Y}_{10}$ & $\mathrm{Ni}_{56.5} \mathrm{Nb}_{32.63} \mathrm{Y}_{10.87}$ & $\mathrm{Ni}_{2} \mathrm{Y}+\mu$ & \\
\hline 19 & $\mathrm{Ni}_{50} \mathrm{Nb}_{25} \mathrm{Y}_{25}$ & $\mathrm{Ni}_{54.74} \mathrm{Nb}_{18.72} \mathrm{Y}_{26.53}$ & $\mathrm{Ni}_{2} \mathrm{Y}+\mathrm{NiY}+\mu$ & \\
\hline 20 & $\mathrm{Ni}_{40} \mathrm{Nb}_{55} \mathrm{Y}_{5}$ & $\mathrm{Ni}_{40.71} \mathrm{Nb}_{54.35} \mathrm{Y}_{4.94}$ & $\mu+(\mathrm{Nb})$ & \\
\hline 21 & $\mathrm{Ni}_{40} \mathrm{Nb}_{50} \mathrm{Y}_{10}$ & $\mathrm{Ni}_{39.46} \mathrm{Nb}_{53.12} \mathrm{Y}_{7.4}$ & $\mathrm{NiY}+\mu+(\mathrm{Nb})$ & \\
\hline 22 & $\mathrm{Ni}_{40} \mathrm{Nb}_{45} \mathrm{Y}_{15}$ & $\mathrm{Ni}_{40.03} \mathrm{Nb}_{46.68} \mathrm{Y}_{13.29}$ & $\mathrm{NiY}+\mu+(\mathrm{Nb})$ & \\
\hline 23 & $\mathrm{Ni}_{40} \mathrm{Nb}_{40} \mathrm{Y}_{20}$ & & $\mathrm{NiY}+(\mathrm{Nb})+\mathrm{Ni}_{2} \mathrm{Y}(\mathrm{a})$ & $\mathrm{NiY}+\mu+(\mathrm{Nb})+\mathrm{Ni}_{2} \mathrm{Y}$ \\
\hline 24 & $\mathrm{Ni}_{40} \mathrm{Nb}_{30} \mathrm{Y}_{30}$ & $\mathrm{Ni}_{40.90} \mathrm{Nb}_{30.34} \mathrm{Y}_{28.76}$ & $\mathrm{NiY}+\mu+(\mathrm{Nb})+\mathrm{Ni}_{2} \mathrm{Y}(\mathrm{a})$ & $\mathrm{NiY}+\mu+(\mathrm{Nb})$ \\
\hline 25 & $\mathrm{Ni}_{40} \mathrm{Nb}_{25} \mathrm{Y}_{35}$ & $\mathrm{Ni}_{41.42} \mathrm{Nb}_{19.94} \mathrm{Y}_{38.64}$ & $\mathrm{NiY}+\mu+(\mathrm{Nb})$ & \\
\hline 26 & $\mathrm{Ni}_{40} \mathrm{Nb}_{20} \mathrm{Y}_{40}$ & $\mathrm{Ni}_{41.46} \mathrm{Nb}_{17.72} \mathrm{Y}_{40.82}$ & $\mathrm{NiY}+(\mathrm{Nb})$ & \\
\hline 27 & $\mathrm{Ni}_{40} \mathrm{Nb}_{10} \mathrm{Y}_{50}$ & $\mathrm{Ni}_{41.12} \mathrm{Nb}_{9.11} \mathrm{Y}_{49.77}$ & $\mathrm{NiY}+(\mathrm{Nb})+\mathrm{Ni}_{2} \mathrm{Y}_{3}$ & $\mathrm{NiY}+(\mathrm{Nb})+\mathrm{Ni}_{2} \mathrm{Y}_{3}$ \\
\hline 28 & $\mathrm{Ni}_{40} \mathrm{Nb}_{5} \mathrm{Y}_{55}$ & & $\mathrm{NiY}+(\mathrm{Nb})+\mathrm{Ni}_{2} \mathrm{Y}_{3}$ & \\
\hline 29 & $\mathrm{Ni}_{35} \mathrm{Nb}_{5} \mathrm{Y}_{60}$ & & $\mathrm{NiY}_{3}+(\mathrm{Nb})+\mathrm{Ni}_{2} \mathrm{Y}_{3}$ & \\
\hline 30 & $\mathrm{Ni}_{30} \mathrm{Nb}_{5} \mathrm{Y}_{65}$ & & $\mathrm{NiY}_{3}+(\mathrm{Nb})+\mathrm{Ni}_{2} \mathrm{Y}_{3}$ & \\
\hline 31 & $\mathrm{Ni}_{20} \mathrm{Nb}_{5} \mathrm{Y}_{75}$ & & $\mathrm{NiY}_{3}+(\mathrm{Nb})+(\mathrm{Y})$ & \\
\hline
\end{tabular}

Table 3 Solubility of third element in binary phases and homogeneity range of solid solutions in the $\mathrm{Nb}-\mathrm{Ni}$ Y system as determined by EPMA after heat treatment for $24 \mathrm{~h}$

\begin{tabular}{llrl}
\hline Phase & \multicolumn{1}{c}{ Equilibrium } & $\begin{array}{c}\text { Heat } \\
\text { treatment, }{ }^{\circ} \mathbf{C}\end{array}$ & \multicolumn{1}{c}{$\begin{array}{c}\text { Solubility, } \\
\text { at. } \%\end{array}$} \\
\hline $\mathrm{NbNi}_{3}$ & $\mathrm{NbNi}_{3}+\mu+\mathrm{Ni}_{2} \mathrm{Y}, \mathrm{NbNi}_{3}+\mathrm{Ni}_{5} \mathrm{Y}$ & 1000 & $0.05(\mathrm{Y})$ \\
$\mu$ & $\mu+\mathrm{Ni}_{2} \mathrm{Y}+\mathrm{NbNi}_{3}$ & 1000 & $0.18(\mathrm{Y})$ \\
$\mathrm{Ni}_{5} \mathrm{Y}$ & $\mathrm{Ni}_{5} \mathrm{Y}+\mathrm{Ni}_{4} \mathrm{Y}+\mathrm{NbNi}_{3}$ & 1000 & $0.2(\mathrm{Nb})$ \\
$\mathrm{Ni}_{3} \mathrm{Y}$ & $\mathrm{Ni}_{3} \mathrm{Y}+\mathrm{Ni}_{7} \mathrm{Y}_{2}+\mathrm{NbNi}_{3}$ & 1000 & $0.5(\mathrm{Nb})$ \\
$\mathrm{Ni}_{2} \mathrm{Y}$ & $\mathrm{Ni}_{2} \mathrm{Y}+\mathrm{NbNi}_{3}+\mu$ & 800 & $0.1(\mathrm{Nb})$ \\
$\mathrm{NiY}$ & $\mathrm{NiY}+\mathrm{Ni}_{2} \mathrm{Y}+\mu$ & 800 & $<0.02(\mathrm{Nb})$ \\
$\mathrm{Ni} \mathrm{Y}_{3}$ & $\mathrm{Ni} \mathrm{Y}_{3}+\mathrm{NiY}+(\mathrm{Nb})$ & 800 & $<0.02(\mathrm{Nb})$ \\
$(\mathrm{Nb})$ & $(\mathrm{Nb})+\mu+\mathrm{NiY}$ & 1000 & $0.1(\mathrm{Y}), 2.0(\mathrm{Ni})$ \\
$(\mathrm{Ni})$ & $(\mathrm{Ni})+\mathrm{Ni}_{5} \mathrm{Y}$ & 1000 & $8.3(\mathrm{Nb})$ \\
\hline
\end{tabular}

mental information of this work using the least-squares optimization module PARROT of the multicomponent thermodynamic software Thermo-Calc. ${ }^{[10]}$ All phase diagrams are calculated with PANDAT software. ${ }^{[11]}$ The final thermodynamic parameters are given in Table 1.

\section{Binary Systems}

In the $\mathrm{Nb}-\mathrm{Ni}$ system, three intermetallic phases, $\mathrm{NbNi}_{8}$ (stable below $535^{\circ} \mathrm{C}$ ), $\mathrm{NbNi}_{3}$, and $\mathrm{Nb}_{7} \mathrm{Ni}_{6}$ ( $\mu$-phase) are known. Terminal solid solutions fcc $(\mathrm{Ni})$ and bec $(\mathrm{Nb})$ show significant homogeneity ranges. Several thermodynamic assessments of the $\mathrm{Nb}-\mathrm{Ni}$ system have been reported in recent years. ${ }^{[8,12,13]}$ In general, the calculated phase diagrams are very similar (in the older work ${ }^{[12]}$ the $\mathrm{NbNi}_{8}$ phase is not present). Differences in the Nb-rich liquidus and in the homogeneity range of the $\mu$-phase are due to the use of different thermodynamic data from literature for the 

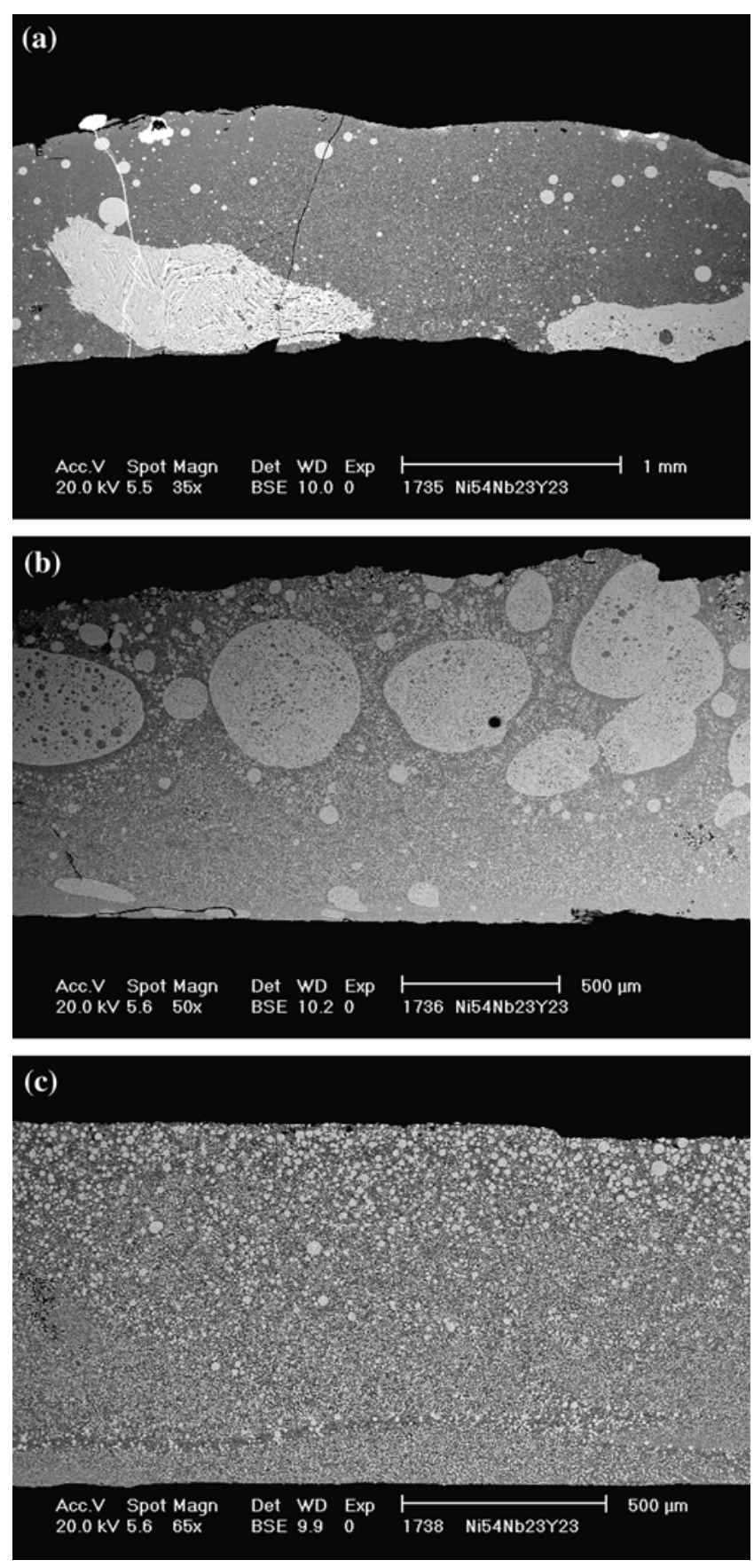

Fig. 5 SEM micrograph of the microstructure of alloy 17 $\left(\mathrm{Ni}_{54.90} \mathrm{Nb}_{25.00} \mathrm{Y}_{20.10}\right)$ levitated and quenched from temperatures of (a) 1300 , (b) 1400 , and (c) $1500{ }^{\circ} \mathrm{C}$

optimization. In the present work, the description of Joubert et al. ${ }^{[8]}$ is selected because of the better agreement with experimental tie-lines in the subsolidus region. The calculated $\mathrm{Nb}-\mathrm{Ni}$ binary phase diagram is shown in Fig. 1.

Nine intermetallic phases exist in the Ni-Y system, that is, $\mathrm{Ni}_{17} \mathrm{Y} 2, \mathrm{Ni}_{5} \mathrm{Y}, \mathrm{Ni}_{4} \mathrm{Y}, \mathrm{Ni}_{7} \mathrm{Y}_{2}, \mathrm{Ni}_{3} \mathrm{Y}, \mathrm{Ni}_{2} \mathrm{Y}, \mathrm{NiY}, \mathrm{Ni}_{2} \mathrm{Y}$, and $\mathrm{NiY}_{3}$. A thermodynamic assessment of the Ni-Y system is reported by $\mathrm{Du}$ and $\mathrm{Zhang}^{[14]}$ and was updated very
Table 4 Chemical compositions of the two immiscible liquids in alloy $17\left(\mathrm{Ni}_{54.90} \mathrm{Nb}_{25.00} \mathrm{Y}_{20.10}\right)$ as determined by EDX after levitation and quenching

\begin{tabular}{llc}
\hline & \multicolumn{2}{c}{ Composition, at.\% } \\
\cline { 2 - 3 } Temperature, ${ }^{\circ} \mathbf{C}$ & Liquid 1 & Liquid 2 \\
\hline 1200 & $\mathrm{Ni}_{50} \mathrm{Nb}_{45} \mathrm{Y}_{5}$ & $\mathrm{Ni}_{58} \mathrm{Nb}_{11} \mathrm{Y}_{31}$ \\
1300 & $\mathrm{Ni}_{50} \mathrm{Nb}_{43} \mathrm{Y}_{7}$ & $\mathrm{Ni}_{58} \mathrm{Nb}_{13} \mathrm{Y}_{29}$ \\
1400 & $\mathrm{Ni}_{50} \mathrm{Nb}_{40} \mathrm{Y}_{10}$ & $\mathrm{Ni}_{58} \mathrm{Nb}_{17} \mathrm{Y}_{25}$ \\
\hline
\end{tabular}

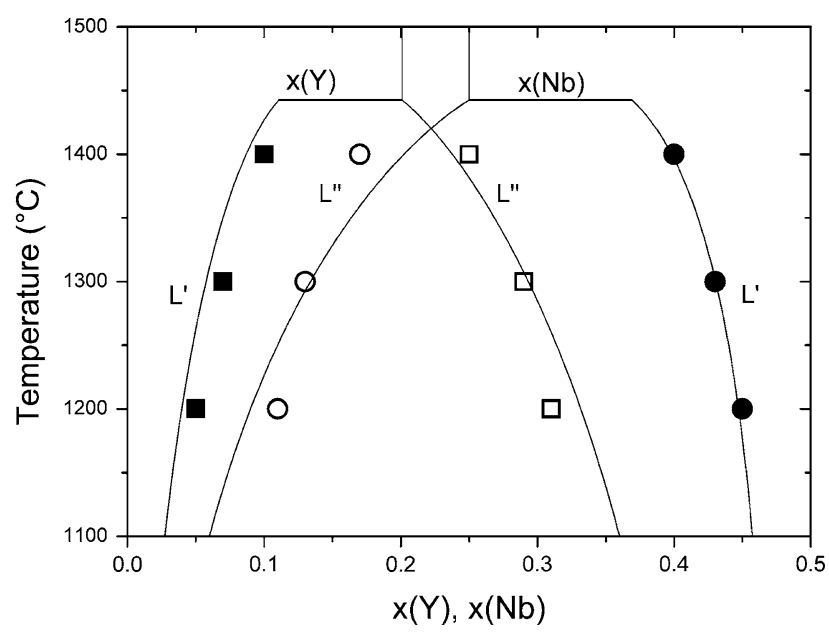

Fig. 6 Calculated $\mathrm{Nb}$ and $\mathrm{Y}$ contents in two liquids in alloy 17 $\left(\mathrm{Ni}_{54.90} \mathrm{Nb}_{25.00} \mathrm{Y}_{20.10}\right)$ compared with experimental data (all solid phases were disregarded). $\mathrm{Nb}$ measurements are given by squares, Y measurements by circles, solid symbols for $\mathrm{L}^{\prime}$, and open symbols for $\mathrm{L}^{\prime \prime}$

recently. ${ }^{[15]}$ It is accepted in the present work with a minor adjustment of parameters of $\mathrm{Ni}_{17} \mathrm{Y}_{2}$ phase to provide a match between experimental and calculated tie-lines in the $\mathrm{Ni}$-rich part of the ternary Nb-Ni-Y system. This modification results in somewhat different values of the enthalpy and entropy of formation of the $\mathrm{Ni}_{17} \mathrm{Y}_{2}$ compound, but not in any changes in calculated phase diagram (Fig. 2). Note that the experimental thermodynamic data for solid phases in the $\mathrm{Ni}-\mathrm{Y}$ system are missing.

An experimental $\mathrm{Nb}-\mathrm{Y}$ phase diagram has been reported by Palenzona and Cirafici. ${ }^{[16]}$ No thermodynamic description is available in the literature. The Nb-Y system is characterized by an extensive immiscibility in the liquid and complete immiscibility in the solid state. The critical temperature of the liquid miscibility gap is unknown. The Gibbs energy parameters of phases in the $\mathrm{Nb}-\mathrm{Y}$ system are estimated in this work based on the limited experimental phase equilibria data ${ }^{[16]}$ and using present results on the extension of the liquid miscibility gap into the ternary $\mathrm{Nb}$ $\mathrm{Ni}-\mathrm{Y}$ system as an additional constraint. All phases are described as substitutional solutions. The calculated $\mathrm{Nb}-\mathrm{Y}$ 
binary phase diagram is shown in Fig. 3. Using regular and subregular interaction parameters for the liquid phase, it was possible to obtain a good fit of the eutectic and monotectic temperatures, $1470 \pm 10{ }^{\circ} \mathrm{C}$ and $\sim 2400{ }^{\circ} \mathrm{C}$, respectively. ${ }^{[16]}$ The eutectic composition is calculated at 97.7 at. $\% \mathrm{Y}$ to compare with the experimental value of $94 \pm 0.5$ at.\%. ${ }^{[16]}$ The agreement can only be improved by using higher-order interaction terms, but the necessary experimental data, especially on liquidus are lacking. The calculated composition of the Y-rich liquid at the monotectic temperature is in good agreement with the value of 54 at. $\%$ Y given in the literature. The yttrium content in the $\mathrm{Nb}$-rich liquid is 5.0 at. \% according to the present assessment. The experimental value is reported as $\sim 0.5$ at. $\%$ and thus cannot be considered reliable. The calculated solid solubilities of $\mathrm{Y}$ in $\mathrm{Nb}$ and vice versa are around 0.1 at.\% in agreement with experimental reports, ${ }^{[16]}$ while niobium has virtually no effect on the temperature of polymorphic cph $\leftrightarrow$ bcc transformation in yttrium metal $\left(1478{ }^{\circ} \mathrm{C}\right)$.

\section{Ternary System}

\subsection{Isothermal Section at $750^{\circ} \mathrm{C}$}

In order to minimize the experimental efforts, the isothermal section of the $\mathrm{Nb}-\mathrm{Ni}-\mathrm{Y}$ system at $750{ }^{\circ} \mathrm{C}$ was first calculated by extrapolation from binary subsystems using Muggianu interpolation of binary excess terms. ${ }^{[17]}$ The interaction parameters ${ }^{0} L_{\mathrm{Nb}, \mathrm{Y}}^{\mathrm{fcc}}$ and ${ }^{0} L_{\mathrm{Nb}, \mathrm{Ni}}^{\mathrm{cph}}$ were given large positive values to avoid the artificial stabilization of fcc and cph phases in the $\mathrm{Nb}-\mathrm{Y}$ and $\mathrm{Nb}-\mathrm{Ni}$ systems, respectively, and in the adjacent regions of the $\mathrm{Nb}-\mathrm{Ni}-\mathrm{Y}$ system. For the $\mathrm{NbNi}_{3}$ and $\mu$-phase, the two and five sublattice models were used as originally proposed by
Joubert et al., ${ }^{[8]}$ while all other phases, that is, $\mathrm{NbNi}_{8},{ }^{[8]}$ and $\mathrm{Ni}-\mathrm{Y}$ intermetallics ${ }^{[15]}$ were treated as stoichiometric compounds. The temperature of $750{ }^{\circ} \mathrm{C}$ was chosen to ensure that all alloys were completely in the solid state. The calculated isothermal section is shown in Fig. 4.

The nominal compositions of alloys for experimental investigation were chosen to check the different three- and two-phase fields suggested by extrapolating calculation. The results of the quantitative phase analysis by XRD and EPMA are summarized in Tables 2 and 3. The results of chemical analysis show (Table 2) that for most alloys the deviation from nominal composition does not exceed 1 at.\%. In general, arc melting resulted in some deficiency of $\mathrm{Y}$ because of the higher evaporation rate of this metal compared with $\mathrm{Nb}$ and $\mathrm{Ni}$. However, the microstructure of some alloys (see below) revealed compositional inhomogeneities because of the liquid immiscibility or primary crystallization of $(\mathrm{Nb})$, which could not be dissolved during subsequent annealing at $750{ }^{\circ} \mathrm{C}$. In such a case, the chemical analysis gives the composition of only a part of the ingot. Some alloys also showed the presence of four phases due to the incomplete equilibration. Since no ternary compounds and no significant solubility of third element in binary solid phases were observed, the subsolidus phase equilibria in the $\mathrm{Nb}-\mathrm{Ni}-\mathrm{Y}$ system were determined by the relative Gibbs energies of phases in binary subsystems; that is, no ternary interaction parameters for solid solutions were required. A comparison of Table 2 and Fig. 4 reveals that the extrapolating calculation is already in agreement with experiment, except the phase relations in the $\mathrm{Ni}$ corner. According to the published thermodynamic description of $\mathrm{Ni}-\mathrm{Y}$ system, ${ }^{[15]} \mathrm{Ni}_{17} \mathrm{Y}_{2}$ forms tie-lines with $\mathrm{NbNi}_{3}$ (dashed line in Fig. 4) instead of experimentally confirmed $\mathrm{Ni}_{17} \mathrm{Y}_{2^{-}}$ (Ni) equilibrium. A small modification of the Gibbs energy expression of $\mathrm{Ni}_{17} \mathrm{Y}_{2}$ phase (see above) removed this inconsistency. In summary, the $750{ }^{\circ} \mathrm{C}$ isothermal section of

Table 5 Calculated temperatures (calc) and compositions of phases at the invariant equilibria in the $\mathrm{Nb}-\mathrm{Ni}-\mathrm{Y}$ system compared with experimental data (exp) of this work

\begin{tabular}{|c|c|c|c|c|c|c|c|c|c|c|}
\hline \multirow{3}{*}{$\begin{array}{l}\text { Equilibrium } \\
\mathrm{U}_{1}: \mathrm{L}+\mathrm{Ni}_{17} \mathrm{Y}_{2} \leftrightarrow \mathrm{Ni}_{5} \mathrm{Y}+(\mathrm{Ni})\end{array}$} & \multicolumn{2}{|c|}{ Temperature, ${ }^{\circ} \mathrm{C}$} & \multicolumn{8}{|c|}{ Calculated } \\
\hline & \multirow{2}{*}{$\begin{array}{l}\text { calc } \\
1247\end{array}$} & \multirow{2}{*}{$\begin{array}{c}\exp \\
1256\end{array}$} & \multicolumn{4}{|c|}{ Y, at. $\%$} & \multicolumn{4}{|c|}{$\mathrm{Nb}$, at. $\%$} \\
\hline & & & 5.4 & 10.5 & 16.7 & $\sim 0$ & 6.3 & nil & nil & 7.9 \\
\hline $\mathrm{U}_{2}: \mathrm{L}+\mathrm{Ni}_{5} \mathrm{Y} \leftrightarrow \mathrm{NbNi}_{3}+\mathrm{Ni}_{4} \mathrm{Y}$ & 1234 & 1235 & 16.4 & 16.7 & nil & 20.0 & 9.4 & nil & 25.0 & nil \\
\hline $\mathrm{U}_{3}: \mathrm{L}+\mathrm{Ni}_{4} \mathrm{Y} \leftrightarrow \mathrm{NbNi}_{3}+\mathrm{Ni}_{7} \mathrm{Y}_{2}$ & 1204 & 1191 & 19.3 & 20.0 & nil & 22.2 & 8.4 & nil & 25.1 & nil \\
\hline $\mathrm{U}_{4}: \mathrm{L}+\mathrm{Ni}_{7} \mathrm{Y}_{2} \leftrightarrow \mathrm{NbNi}_{3}+\mathrm{Ni}_{3} \mathrm{Y}$ & 1162 & 1161 & 22.9 & 22.2 & nil & 25.0 & 7.1 & nil & 25.1 & nil \\
\hline $\mathrm{U}_{5}: \mathrm{L}+\mathrm{Ni}_{3} \mathrm{Y} \leftrightarrow \mathrm{NbNi}_{3}+\mathrm{Ni}_{2} \mathrm{Y}$ & 1058 & 1063 & 30.7 & 25.0 & nil & 33.3 & 4.0 & nil & 25.3 & nil \\
\hline $\mathrm{U}_{6}: \mathrm{L}+\mathrm{NbNi}_{3} \leftrightarrow \mu+\mathrm{Ni}_{2} \mathrm{Y}$ & 1026 & 1035 & 33.0 & nil & nil & 33.3 & 4.2 & 25.7 & 48.9 & nil \\
\hline $\mathrm{U}_{7}: \mathrm{L}+(\mathrm{Nb}) \leftrightarrow \mu+\mathrm{NiY}$ & 1021 & 1008 & 44.4 & $\sim 0$ & nil & 50.0 & 1.2 & 96.9 & 58.4 & nil \\
\hline $\mathrm{E}_{1}: \mathrm{L} \leftrightarrow \mathrm{Ni}_{5} \mathrm{Y}+(\mathrm{Ni})+\mathrm{NbNi}_{3}$ & 1227 & 1224 & 4.2 & 16.7 & $\sim 0$ & nil & 10.2 & nil & 11.0 & 23.3 \\
\hline $\mathrm{E}_{2}: \mathrm{L} \leftrightarrow \mu+\mathrm{Ni}_{2} \mathrm{Y}+\mathrm{NiY}$ & 936 & 930 & 41.0 & nil & 33.3 & 50.0 & 1.1 & 53.2 & nil & nil \\
\hline $\mathrm{M}_{1}: \mathrm{L}^{\prime}+\mathrm{L}^{\prime \prime}+(\mathrm{Nb}) \leftrightarrow \mu$ & 1262 & 1304 & 5.0 & 31.0 & $\sim 0$ & nil & 43.8 & 11.5 & 95.6 & 59.6 \\
\hline $\mathrm{D}_{1}: \mathrm{L}+(\mathrm{Nb})+(\mathrm{Y}) \leftrightarrow \mathrm{NiY}_{3}$ & 902 & 895 & 72.9 & $\sim 0$ & 99.9 & 75.0 & $\sim 0$ & 99.9 & $\sim 0$ & nil \\
\hline $\mathrm{D}_{2}: \mathrm{L}+(\mathrm{Nb}) \leftrightarrow \mathrm{Ni}_{2} \mathrm{Y}_{3}+\mathrm{NiY}_{3}$ & 805 & 802 & 64.8 & $\sim 0$ & 60.0 & 75.0 & $\sim 0$ & 99.8 & nil & nil \\
\hline $\mathrm{D}_{3}: \mathrm{L}+(\mathrm{Nb})+\mathrm{NiY} \leftrightarrow \mathrm{Ni}_{2} \mathrm{Y}_{3}$ & 820 & 809 & 62.6 & $\sim 0$ & 50.0 & 60.0 & $\sim 0$ & 99.8 & nil & nil \\
\hline $\mathrm{e}_{1}(\max ): \mathrm{L} \leftrightarrow \mathrm{Ni}_{5} \mathrm{Y}+\mathrm{NbNi}_{3}$ & 1291 & & 7.9 & 16.7 & nil & $\cdots$ & 11.8 & nil & 24.5 & $\cdots$ \\
\hline $\mathrm{e}_{2}(\max ): \mathrm{L} \leftrightarrow \mathrm{NiY}+(\mathrm{Nb})$ & 1059 & & 50.5 & 50.0 & $\sim 0$ & $\cdots$ & 0.6 & nil & 98.3 & $\cdots$ \\
\hline
\end{tabular}



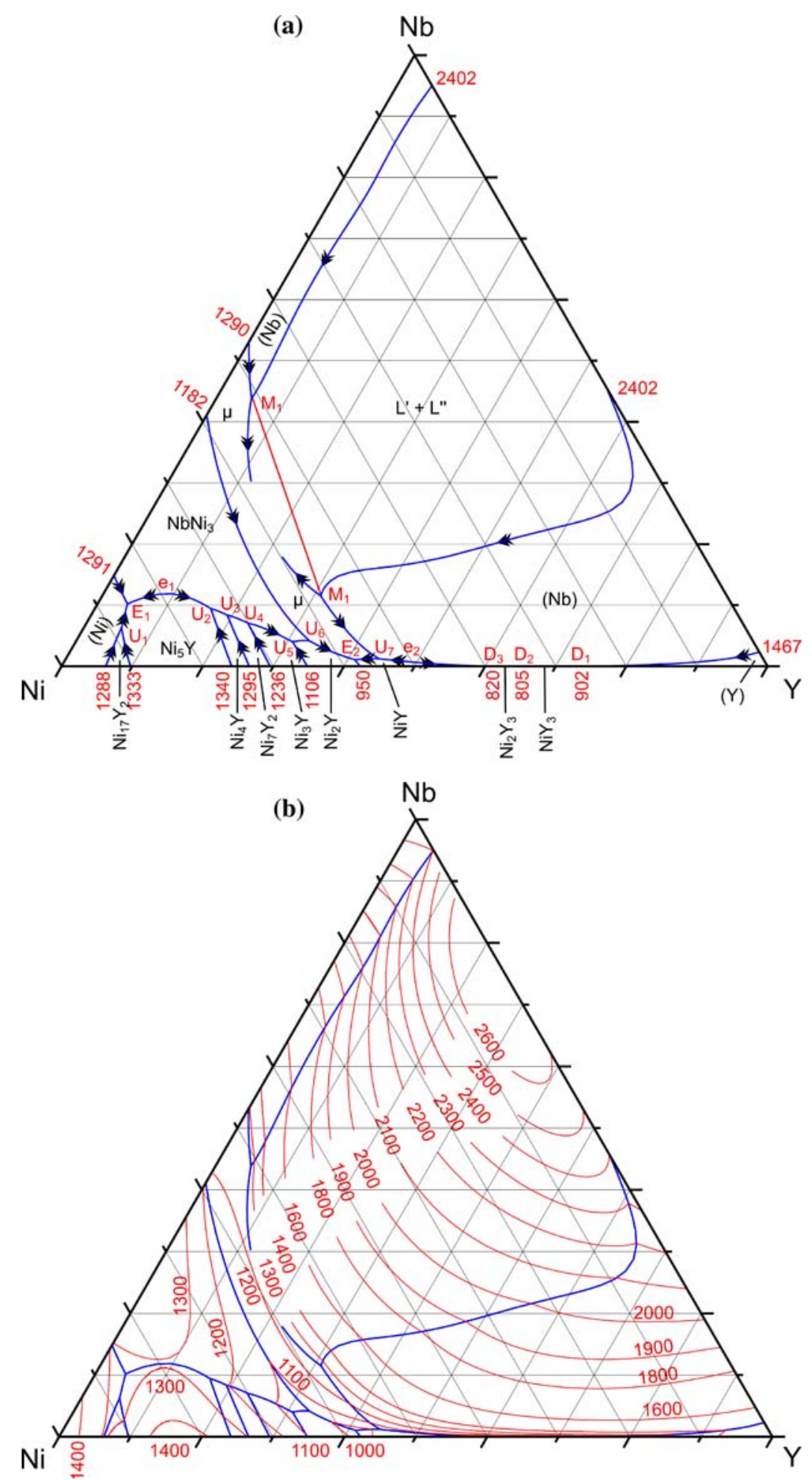

Fig. 7 Calculated projection of liquidus surface in the ternary Nb-Ni-Y system in atomic percents. (a) Monovariant liquidus lines with the indicated fields of primary crystallization and invariant points. (b) Liquidus isotherms in ${ }^{\circ} \mathrm{C}$

the $\mathrm{Nb}-\mathrm{Ni}-\mathrm{Y}$ system in the Ni-rich part is dominated by the $\mathrm{NbNi}_{3}$ phase, which forms tie-lines with $\mathrm{Ni}_{5} \mathrm{Y}, \mathrm{Ni}_{4} \mathrm{Y}, \mathrm{Ni}_{7} \mathrm{Y}_{2}$, $\mathrm{Ni}_{3} \mathrm{Y}$, and $\mathrm{Ni}_{2} \mathrm{Y}$, while beyond 50 at. $\% \mathrm{Y}$ it consists of equilibria formed by $(\mathrm{Nb})$ with $\mathrm{NiY}, \mathrm{Ni}_{2} \mathrm{Y}_{3}$, and $\mathrm{NiY}_{3}$. The $\mu$-phase of Nb-Ni system is stable in the intermediate range of compositions and coexists with both $\mathrm{Ni}_{2} \mathrm{Y}$ and $\mathrm{NiY}$. 

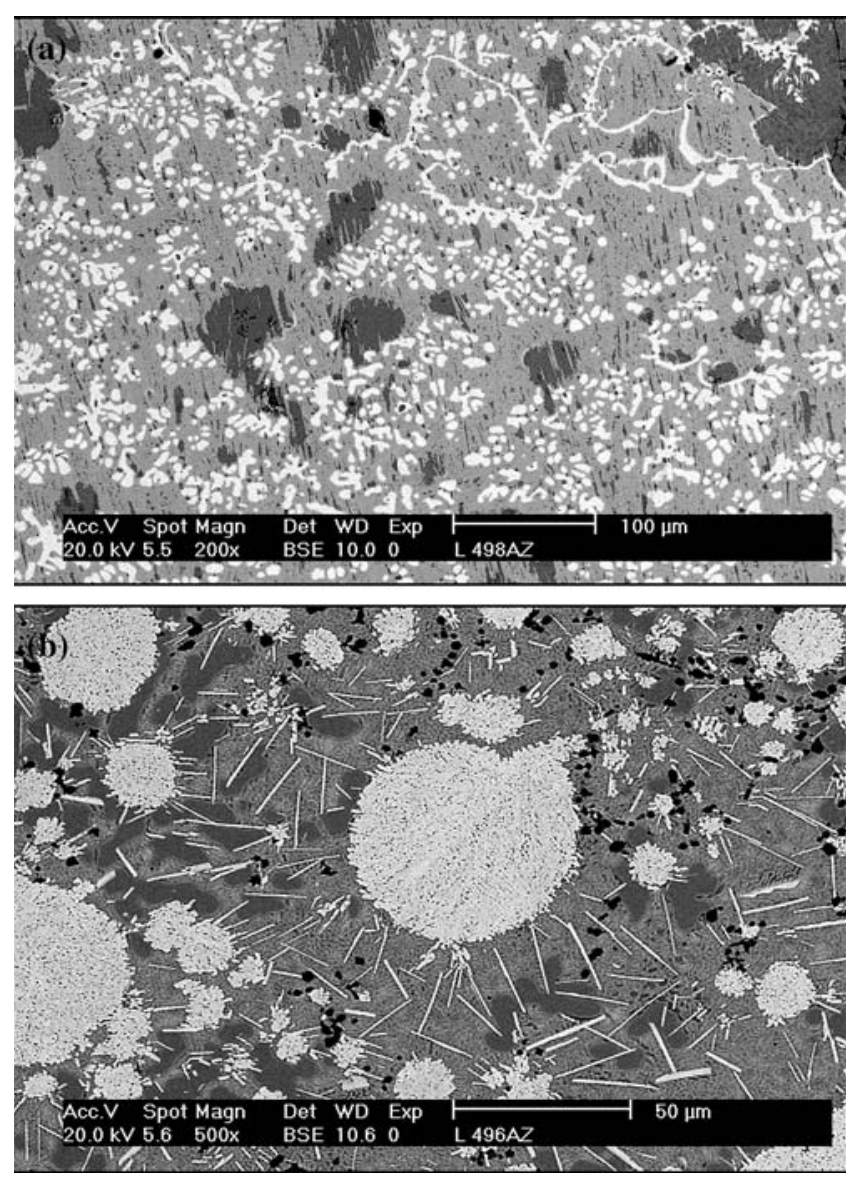

Fig. 8 SEM micrographs of the solidification microstructures of alloys within the liquid immiscibility region. (a) Alloy 23 $\left(\mathrm{Ni}_{40} \mathrm{Nb}_{40} \mathrm{Y}_{20}\right)$ : white, $(\mathrm{Nb})$; gray matrix, $\mu$; dark, NiY. (b) Alloy $19\left(\mathrm{Ni}_{54.74} \mathrm{Nb}_{18.72} \mathrm{Y}_{26.53}\right)$ : light spherical particles and needles, $\mu$; dark, $\mathrm{Ni}_{2} \mathrm{Y}$; gray matrix, $\mu+\mathrm{Ni}_{2} \mathrm{Y}+\mathrm{NiY}$; black spots, pores

\subsection{Liquid Immiscibility}

Extrapolating calculation revealed a quite extensive protrusion of the liquid miscibility gap from the $\mathrm{Nb}-\mathrm{Y}$ binary into the ternary $\mathrm{Nb}-\mathrm{Ni}-\mathrm{Y}$ system. Indeed, the microstructures of the solidified alloys 17, 19, 23, and 24 suggest that a phase separation into two liquids took place before a primary crystallization occurred. Experimental information on the ternary liquid miscibility gap was obtained by analyzing the microstructure of samples, which had been levitated in the liquid state and quenched. Figure 5 shows SEM micrographs of the microstructure of alloy 17 quenched from three different temperatures, as an example. For $T=1300$ (Fig. 5a) and $1400{ }^{\circ} \mathrm{C}$ (Fig. 5b) large inhomogeneities are visible, $\mathrm{Nb}$-enriched white regions and $\mathrm{Y}$ enriched gray regions. Also some spherical white precipitates confirm that this microstructure is caused by the phase separation in the melt. At the same time, the microstructure of the sample quenched from $1500{ }^{\circ} \mathrm{C}$ (Fig. 5c) shows only small particles or spheres of Ni-Nb phases within the Ni-Y matrix. These particles are formed by phase separation of the homogeneous liquid during quenching followed by the crystallization. The critical temperature is evident in the
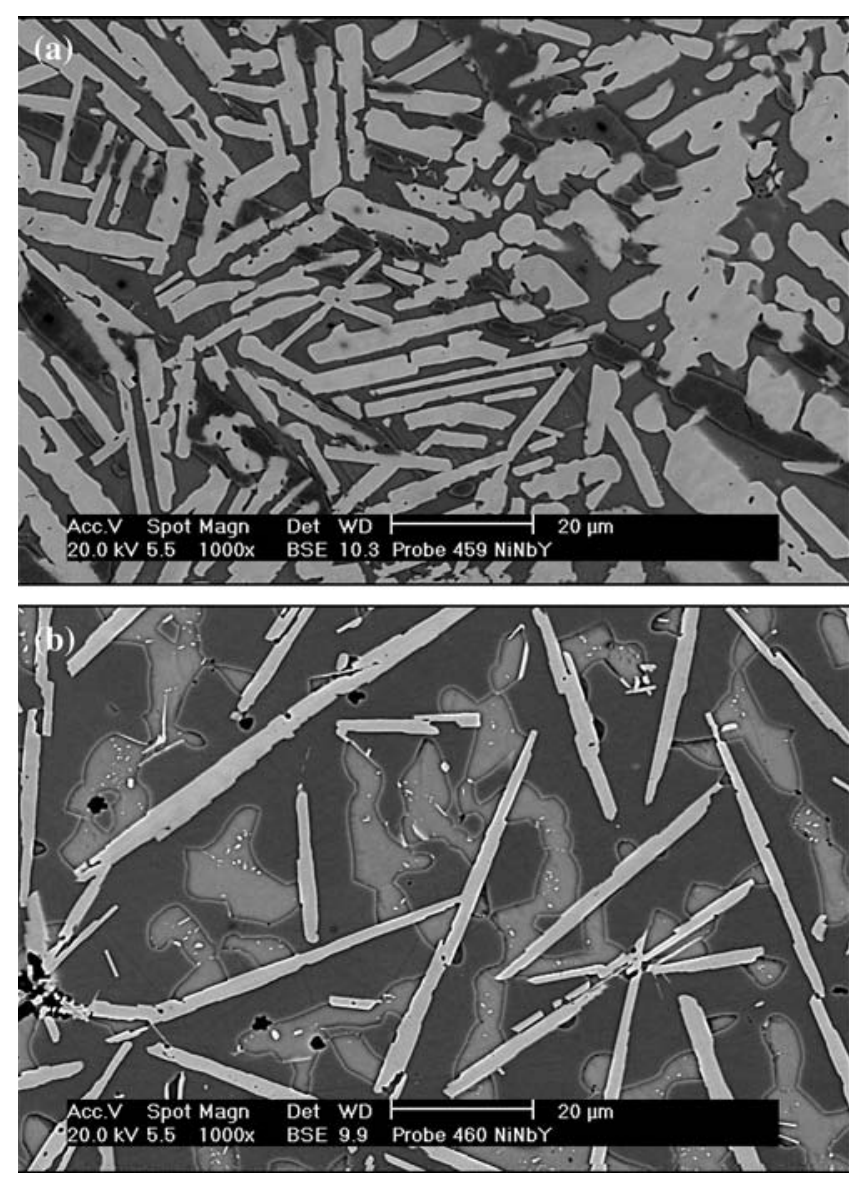

Fig. 9 SEM micrographs of the solidification microstructures of alloys in the region of the primary crystallization of the $\mu$-phase. (a) Alloy $14\left(\mathrm{Ni}_{60.22} \mathrm{Nb}_{29.30} \mathrm{Y}_{10.47}\right)$ : white, $\mu$; gray matrix, $\mathrm{Ni}_{2} \mathrm{Y}$; dark, $\mathrm{NbNi}_{3}$. (b) Alloy $16\left(\mathrm{Ni}_{60.47} \mathrm{Nb}_{10.03} \mathrm{Y}_{29.50}\right)$ : white needles, $\mu$; dark, $\mathrm{Ni}_{2} \mathrm{Y}$; gray, $\mathrm{NiY}$

DSC curve by an endothermic event at $T=1475{ }^{\circ} \mathrm{C}$ upon heating. The chemical compositions of both the liquid phases in alloy 17 were determined by EDX analysis integrating over large regions of the individual particles. The results (Table 4) indicate that apart from the Nb:Y ratio, the melts are different in Ni content.

The calculated $\mathrm{Nb}$ and $\mathrm{Y}$ contents in two liquids in alloy 17 are in reasonable agreement with experimental data, as shown in Fig. 6. All solid phases were disregarded in the calculation to allow the metastable extrapolation to low temperatures. The critical temperature of the miscibility gap for this composition was predicted at $1443{ }^{\circ} \mathrm{C}$. It should be noted that the plots shown do not represent a vertical section through the $\mathrm{Nb}-\mathrm{Ni}-\mathrm{Y}$ phase diagram because of different $\mathrm{Ni}$ contents in the two liquids.

\subsection{Solidification Behavior and Projection of Liquidus Surface}

The equilibrium solidification paths of alloys 1 to 11,14 to $16,19,23,24$, and 27 to 31 were reconstructed by analyzing their arc melted, as-cast microstructures. This 

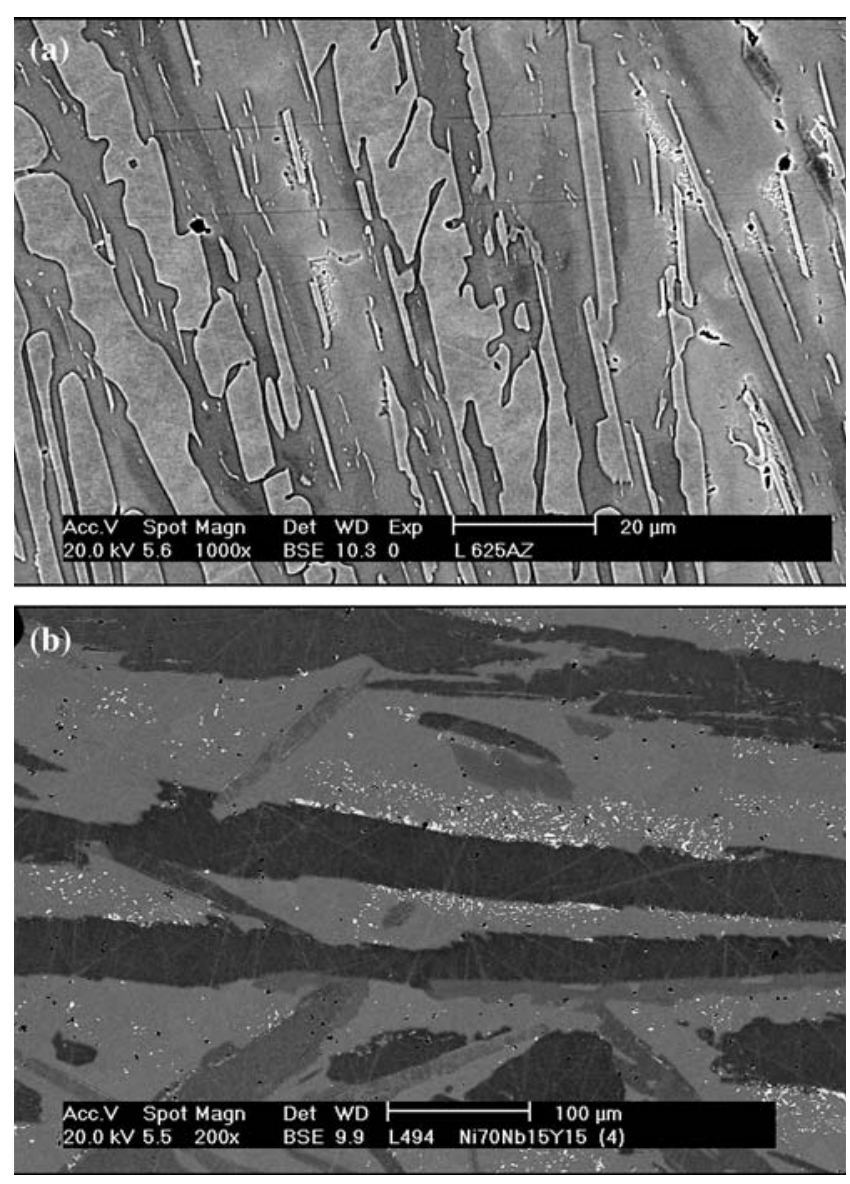

Fig. 10 SEM micrographs of the solidification microstructures of alloys in the region of the primary crystallization of $\mathrm{NbNi}_{3}$. (a) Alloy $9\left(\mathrm{Ni}_{75} \mathrm{Nb}_{12.5} \mathrm{Y}_{12.5}\right)$ : light elongated grains, $\mathrm{NbNi}_{3}$; gray matrix, $\mathrm{Ni}_{3} \mathrm{Y}$; dark, $\mathrm{Ni}_{7} \mathrm{Y}_{2}$. (b) Alloy $11\left(\mathrm{Ni}_{71.77} \mathrm{~N}-\right.$ $\mathrm{b}_{13.2} \mathrm{Y}_{15.03}$ ): large and dark areas, primary $\mathrm{NbNi}_{3}$; middle gray shells around primary $\mathrm{NbNi}_{3}, \mathrm{Ni}_{3} \mathrm{Y}$; gray matrix, $\mathrm{Ni}_{2} \mathrm{Y}$; small elongated grains within this matrix, secondary $\mathrm{NbNi}_{3}$; white particles, $\mu$

qualitative information was used together with the temperatures of invariant reactions determined by DSC (Table 5) and the data on liquid miscibility gap (Table 4) to optimize the composition-dependent ternary interaction parameter of the liquid phase. The experimental temperatures of fourphase equilibria are well reproduced by the calculation. The absence of systematic errors is evident from the measured temperatures of degenerated invariant reactions $D_{1}, D_{2}$, and $D_{3}$, which coincide with the corresponding temperatures in the binary Ni-Y system (Fig. 2) within $\pm 10{ }^{\circ} \mathrm{C}$. The calculated projection of liquidus surface is shown in Fig. 7. The largest area in this projection is occupied by the miscibility gap, which originates from the $\mathrm{Nb}-\mathrm{Y}$ binary system and penetrates up to almost 60 at.\% Ni. The solidification behavior in the ternary $\mathrm{Nb}-\mathrm{Ni}-\mathrm{Y}$ system is dominated by $(\mathrm{Nb}), \mu, \mathrm{NbNi}_{3}$, and $\mathrm{Ni}_{5} \mathrm{Y}$ phases and governed by one monotectic, two eutectic, and seven transitional invariant reactions. In addition, two invariant three-phase equilibria (Table 5) are found by calculation. The existence of these maxima is related to the congruent melting character of the $\mathrm{Ni}_{5} \mathrm{Y}$ and $\mathrm{NiY}$ phases, while their location in the projection is fully consistent with the observed solidification paths, as shown below.

The representative solidification microstructures of the alloys within the liquid immiscibility region are shown in Fig. 8. At high temperatures, alloy 23 is located in the threephase field, where the primary $(\mathrm{Nb})$ phase coexists with the two liquids, one of them vanishing at the monotectic fourphase equilibrium, $\mathrm{L}^{\prime}+\mathrm{L}^{\prime \prime}+(\mathrm{Nb}) \leftrightarrow \mu\left(\mathrm{M}_{1}\right)$. The remaining liquid then solidifies according to the monovariant peritectic reaction, $\mathrm{L}^{\prime \prime}+(\mathrm{Nb}) \leftrightarrow \mu$, until the solidus is reached at the ternary eutectic $\mathrm{E}_{2}, \mathrm{~L}^{\prime \prime} \leftrightarrow \mu+\mathrm{Ni}_{2} \mathrm{Y}+\mathrm{NiY}$, due to uncompleted transitional reaction $\mathrm{U}_{7}, \mathrm{~L}^{\prime \prime}+(\mathrm{Nb}) \leftrightarrow$ $\mu+\mathrm{NiY}$. Note the substantial erosion of the primary $(\mathrm{Nb})$ dendrites, which appear as colonies of white particles in Fig. $8(\mathrm{a})$. In alloy $19, \mu$ is formed as a primary solid phase from the miscibility gap. Upon further decreasing temperature one of the liquids freezes completely (spherical particles in Fig. 8b), while the other still continues to precipitate the primary $\mu$-phase of needlelike morphology. The appearance of dark shells around the needles can be understood as a result of the monovariant eutectic reaction, $\mathrm{L}^{\prime \prime} \leftrightarrow \mu+\mathrm{Ni}_{2} \mathrm{Y}$, while the solidification ends at the ternary eutectic $E_{2}$ (note the very fine microstructure of the gray matrix in Fig. 8b).

The field of primary crystallization of the $\mu$-phase shows a quite large extension toward the $\mathrm{Ni}-\mathrm{Y}$ edge and is partially intersected by the liquid miscibility gap (Fig. 7) at the temperature of the monotectic four-phase equilibrium. The tie-line $\mathrm{M}_{1}-\mathrm{M}_{1}$ connects the equilibrium compositions of the two liquids. The solidification microstructures of two alloys in the region of the primary crystallization of the $\mu$-phase are shown in Fig. 9. In both alloys the monovariant eutectic reaction, $\mathrm{L} \leftrightarrow \mu+\mathrm{Ni}_{2} \mathrm{Y}$, takes place; however, in alloy 14 it is preceded by the monovariant reaction, $\mathrm{L} \leftrightarrow \mu+\mathrm{NbNi}_{3}$, because of the higher $\mathrm{Nb}$ content. Because of this difference in composition, the solidification of alloy 14 stops after passing the transitional four-phase equilibrium $\mathrm{U}_{6}, \mathrm{~L}+$ $\mathrm{NbNi}_{3} \leftrightarrow \mu+\mathrm{Ni}_{2} \mathrm{Y}$, while the solidus of alloy 16 corresponds to the ternary eutectic reaction $\mathrm{E}_{2}$.

The solidification of alloys 9 and 11 begins with the precipitation of the primary $\mathrm{NbNi}_{3}$ crystals (Fig. 10). In alloy 9 it is directly followed by the monovariant peritectic reaction, $\mathrm{L}+\mathrm{NbNi}_{3} \leftrightarrow \mathrm{Ni}_{7} \mathrm{Y}_{2}$; the remaining liquid freezes completely at the transitional four-phase equilibrium $\mathrm{U}_{4}$, $\mathrm{L}+\mathrm{Ni}_{7} \mathrm{Y}_{2} \leftrightarrow \mathrm{NbNi}_{3}+\mathrm{Ni}_{3} \mathrm{Y}$. Interestingly, two different morphologies of the $\mathrm{NbNi}_{3}$ phase are observed in alloy 11 (Fig. 10b) as a consequence of passing through two invariant transitional reactions: $\mathrm{U}_{5}, \mathrm{~L}+\mathrm{Ni}_{3} \mathrm{Y} \leftrightarrow \mathrm{NbNi}_{3}+$ $\mathrm{Ni}_{2} \mathrm{Y}$, and $\mathrm{U}_{6}, \mathrm{~L}+\mathrm{NbNi}_{3} \leftrightarrow \mu+\mathrm{Ni}_{2} \mathrm{Y}$. After the primary $\mathrm{NbNi}_{3}$ crystals are formed, the binary monovariant peritectic eutectic crystallization of $\mathrm{Ni}_{3} \mathrm{Y}$ takes place; that is, $\mathrm{L} \leftrightarrow$ $\mathrm{NbNi}_{3}+\mathrm{Ni}_{3} \mathrm{Y}$. This phase is then partially consumed at the four-phase equilibrium $\mathrm{U}_{5}, \mathrm{~L} \leftrightarrow \mathrm{Ni}_{3} \mathrm{Y}+\mathrm{Ni}_{2} \mathrm{Y}$, which results in appearance of the secondary $\mathrm{NbNi}_{3}$ within the $\mathrm{Ni}_{2} \mathrm{Y}$ matrix. The final stage of solidification of this alloy corresponds to the invariant reaction $\mathrm{U}_{6}$, thus forming very fine $\mu$-precipitates. It remains to note that in alloy 9 , the monovariant reaction involving the phases $\mathrm{L}, \mathrm{NbNi}_{3}$, and $\mathrm{Ni}_{7} \mathrm{Y}_{2}$ should be preceded by another one involving the 

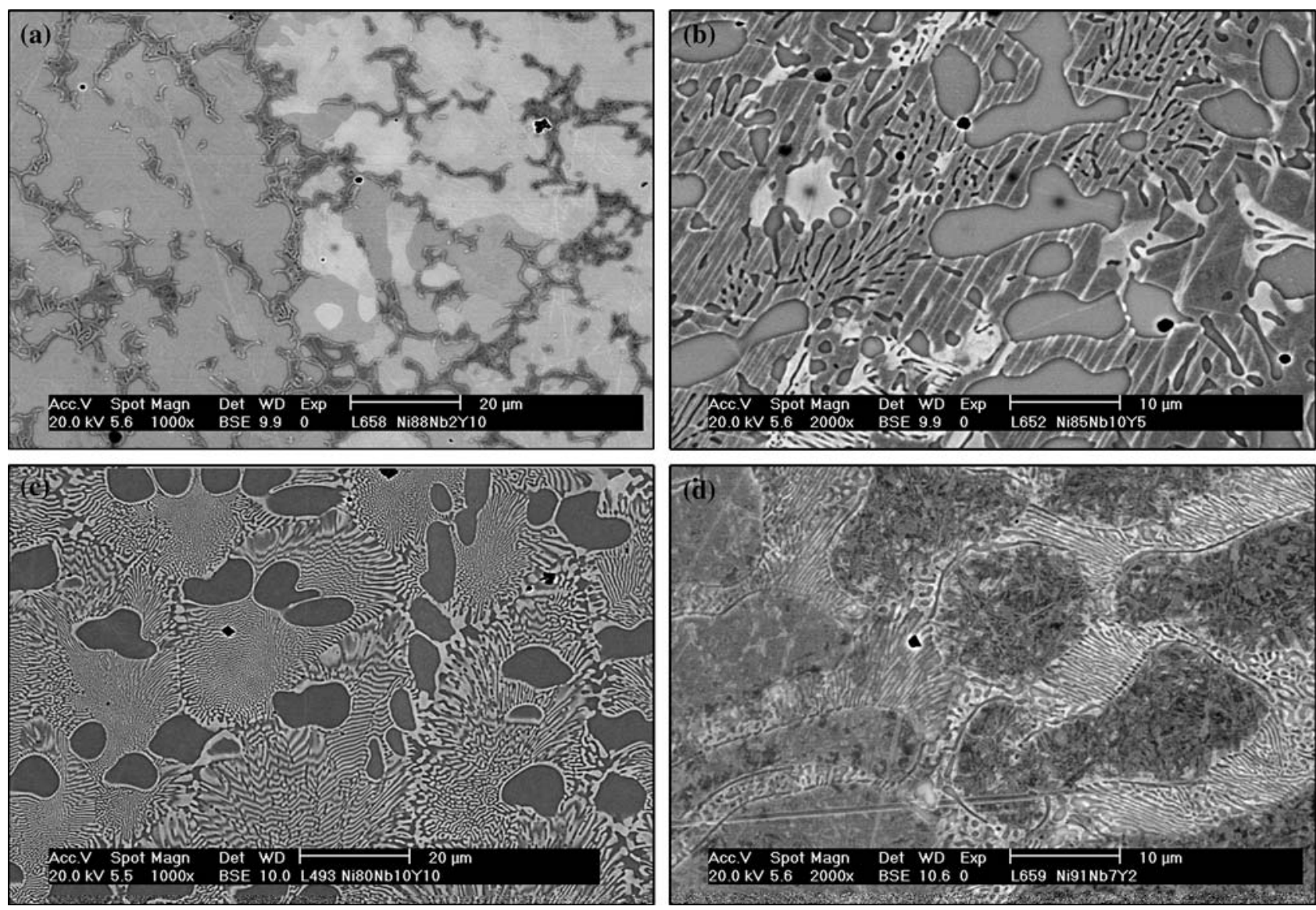

Fig. 11 SEM micrographs of the solidification microstructures of Ni-rich alloys. (a) Alloy $2\left(\mathrm{Ni}_{88.35} \mathrm{Nb}_{2.04} \mathrm{Y}_{9.61}\right)$ : gray, $\mathrm{Ni}_{5} \mathrm{Y}$; light, $\mathrm{Ni}_{5} \mathrm{Y}+\mathrm{Ni}_{17} \mathrm{Y}_{2}$; dark patterned areas, $\mathrm{Ni}_{5} \mathrm{Y}+(\mathrm{Ni})$. (b) Alloy $3\left(\mathrm{Ni}_{85.16} \mathrm{Nb}_{9.92} \mathrm{Y}_{4.92}\right)$ : gray, $\mathrm{Ni}_{5} \mathrm{Y}$; patterned matrix, $\mathrm{Ni} \mathrm{i}_{5} \mathrm{Y}+(\mathrm{Ni})+\mathrm{NbNi}{ }_{3}$; white inclusions, $\mathrm{NbNi}_{3}$. (c) Alloy $5\left(\mathrm{Ni}_{80.38} \mathrm{Nb}_{9.99} \mathrm{Y}_{9.63}\right)$ : dark grains, $\mathrm{Ni}_{5} \mathrm{Y}$; patterned areas (coarse), $\mathrm{Ni}_{5} \mathrm{Y}+\mathrm{NbNi}_{3}$; patterned areas (fine), $\mathrm{Ni}_{5} \mathrm{Y}+(\mathrm{Ni})+\mathrm{NbNi}_{3}$. (d) Alloy $1\left(\mathrm{Ni}_{91.00} \mathrm{Nb}_{7.03} \mathrm{Y}_{1.97}\right)$ : gray, (Ni); light patterned areas, $\mathrm{Ni}+\mathrm{Ni}_{17} \mathrm{Y}_{2}$

phases $\mathrm{L}, \mathrm{NbNi}_{3}$, and $\mathrm{Ni}_{4} \mathrm{Y}$. However, the amount of $\mathrm{Ni}_{4} \mathrm{Y}$ formed after primary precipitation of $\mathrm{NbNi}_{3}$ is probably so small that this phase is totally consumed through the invariant reaction $\mathrm{U}_{3}$.

The solidification microstructures of Ni-rich alloys are shown in Fig. 11. Alloys 2, 3, 4, and 5 show the primary crystallization of $\mathrm{Ni}_{5} \mathrm{Y}$. Depending on composition three different solidification paths are recognized. The Nb-poor alloy 2 (Fig. 11a) exhibits the monovariant peritectic formation of the $\mathrm{Ni}_{17} \mathrm{Y}_{2}$ phase according to the reaction, $\mathrm{L}+\mathrm{Ni}_{5} \mathrm{Y} \leftrightarrow \mathrm{Ni}_{17} \mathrm{Y}_{2}$ and freezes completely at the monovariant eutectic $\mathrm{L} \leftrightarrow(\mathrm{Ni})+\mathrm{Ni}_{5} \mathrm{Y} \quad\left(\mathrm{U}_{1}-\mathrm{E}_{1}\right)$. The former contains 7.3 at. $\% \mathrm{Nb}$ as determined by EDX analysis. The microstructure of alloys 3 and 4 (Fig. 11b) shows the signs of monovariant eutectic reaction, $\mathrm{L} \leftrightarrow \mathrm{NbNi}_{3}+\mathrm{Ni}_{5} \mathrm{Y}$, while the solidification stops at the ternary eutectic $\mathrm{E}_{1}, \mathrm{~L} \leftrightarrow$ $\mathrm{Ni}_{5} \mathrm{Y}+(\mathrm{Ni})+\mathrm{NbNi}_{3}$. A pseudobinary eutectic microstructure corresponding to $\mathrm{e}_{1}$ is seen very clearly in alloy 5 (Fig. 11c). The eutectic composition is measured by EDX as $\mathrm{Ni}_{80.6} \mathrm{Nb}_{12.0} \mathrm{Y}_{7.4}$ (at.\%), and similar values are obtained from thermodynamic calculations (Table 5). The primary crystals in alloy 1 consist of $(\mathrm{Ni})$ solid solution, which contains 8.3 at.\% $\mathrm{Nb}$ (Fig. 11d). The solidification contin- ues via the monovariant reaction, $\mathrm{L} \leftrightarrow(\mathrm{Ni})+\mathrm{Ni}_{17} \mathrm{Y}_{2}$ and should stop at the transitional four-phase equilibrium $\mathrm{U}_{1}$. However, the $\mathrm{Ni}_{5} \mathrm{Y}$ phase cannot be detected in the microstructure because of its low amount.

Figure 12 shows the solidification microstructures of alloys 29, 30, and 31, all containing 5 at.\% $\mathrm{Nb}$. After primary crystallization of $(\mathrm{Nb})$, which is seen in all the alloys as white dendrites, the solidification paths depend on composition. In alloy 29 , first the monovariant eutectic reaction, $\mathrm{L} \leftrightarrow(\mathrm{Nb})+\mathrm{NiY}$ takes place and then, after passing the four-phase equilibrium $\mathrm{D}_{3}, \mathrm{~L}+(\mathrm{Nb})+\mathrm{NiY} \leftrightarrow$ $\mathrm{Ni}_{2} \mathrm{Y}_{3}$, the solidification continues via the growth of the $\mathrm{Ni}_{2} \mathrm{Y}_{3}$ phase followed by the monovariant reaction, $\mathrm{L}+$ $\mathrm{Ni}_{2} \mathrm{Y}_{3} \leftrightarrow \mathrm{NiY}_{3}$, and ends at another invariant equilibrium $\mathrm{D}_{2}, \mathrm{~L}+(\mathrm{Nb}) \leftrightarrow \mathrm{Ni}_{2} \mathrm{Y}_{3}+\mathrm{NiY}_{3}$. The microstructure of alloy 30 (Fig. 12b) suggests the secondary crystallization of the $\mathrm{NiY}_{3}$ phase through the monovariant eutectic reaction, $\mathrm{L} \leftrightarrow(\mathrm{Nb})+\mathrm{NiY}_{3}$, which is finished at the four-phase equilibrium $\mathrm{D}_{2}$. In alloy 31 , the monovariant peritectic reaction, $\mathrm{L}+(\mathrm{Nb}) \leftrightarrow(\mathrm{Y})$ occurs (Fig. 12c), while the solidus is reached at the invariant equilibrium $D_{1}$, $\mathrm{L}+(\mathrm{Nb})+(\mathrm{Y}) \leftrightarrow \mathrm{NiY}_{3}$. Note that the area marked with $(\mathrm{Nb})$ in Fig. 7 comes very close to the Ni-Y boundary, so 

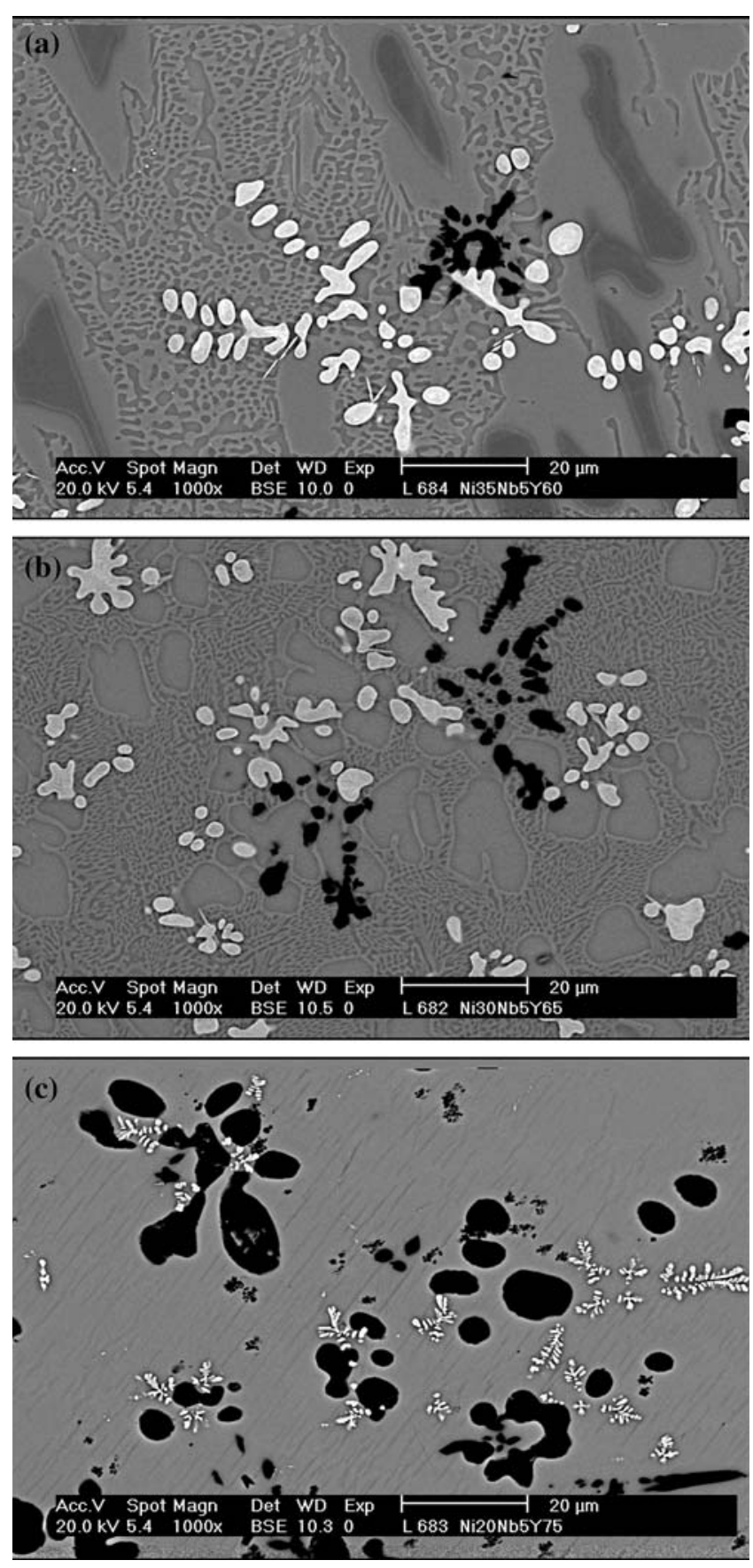

Fig. 12 SEM micrographs of the solidification microstructures of alloys with 5 at. $\% \mathrm{Nb}$. (a) Alloy $29\left(\mathrm{Ni}_{35} \mathrm{Nb}_{5} \mathrm{Y}_{60}\right)$ : white, $(\mathrm{Nb})$; black, $\mathrm{NiY}$; dark gray, $\mathrm{Ni}_{2} \mathrm{Y}_{3}$; light gray, $\mathrm{NiY}_{3}$; patterned area, $\mathrm{NiY}_{3}+\mathrm{Ni}_{2} \mathrm{Y}_{3}$. (b) Alloy $30\left(\mathrm{Ni}_{30} \mathrm{Nb}_{5} \mathrm{Y}_{65}\right)$ : white, (Nb); gray rounded particles, $\mathrm{NiY}_{3}$; patterned area, $\mathrm{NiY}_{3}+\mathrm{Ni}_{2} \mathrm{Y}_{3}$; black dendrites $(\mathrm{Y})$, nonequilibrium inclusions from arc melting. (c) Alloy $31\left(\mathrm{Ni}_{20} \mathrm{Nb}_{5} \mathrm{Y}_{75}\right)$ : white, $(\mathrm{Nb})$; black, $(\mathrm{Y})$; gray matrix, $\mathrm{NiY}_{3}$

that the four-phase equilibria $\mathrm{D}_{1}, \mathrm{D}_{2}$, and $\mathrm{D}_{3}$ degenerate; that is, the liquid contains very little $\mathrm{Nb}$, and thus the temperatures are not significantly different from the corresponding temperatures of three-phase equilibria in the binary Ni-Y system.
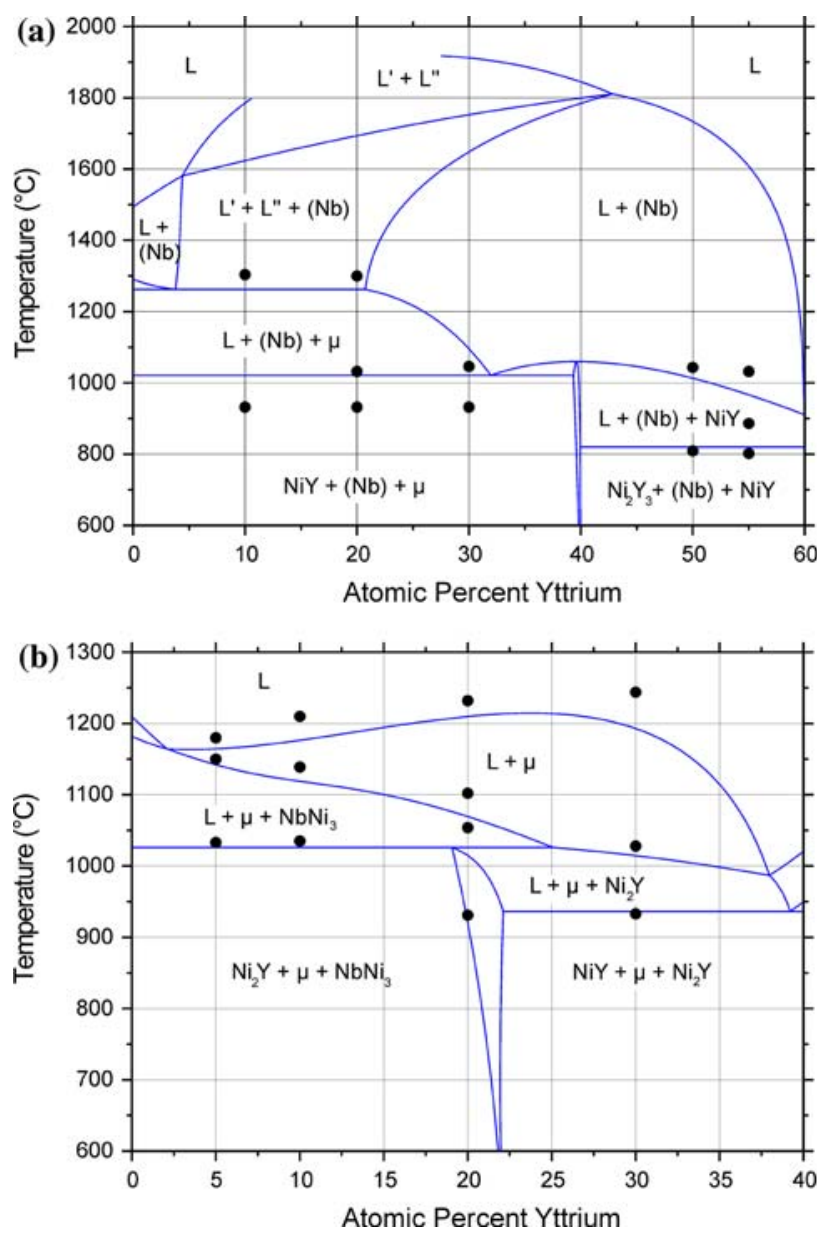

Fig. 13 Calculated temperature-composition sections of the $\mathrm{Nb}$ $\mathrm{Ni}-\mathrm{Y}$ phase diagram at 40 at.\% Ni (a) and 60 at.\% Ni (b) superimposed with experimental DSC data of this work

\subsection{Temperature-Composition Sections}

The calculated temperature-composition sections of the $\mathrm{Nb}-\mathrm{Ni}-\mathrm{Y}$ phase diagram are shown in Fig. 13 to 15 , where solid circles correspond to the transitions from one phase field to another at the particular compositions. These temperatures are determined by the analysis of DSC heating curves as proposed by Gödecke. ${ }^{[18]}$ It should be noted that because of the finite heating rate as well as the possible shifts in compositions and partial equilibration of alloys with high niobium contents, these temperatures may not be identical with those that would be measured in equilibrium conditions. Therefore, only temperatures of invariant equilibria, which appear in the sections as horizontal lines, are used in the thermodynamic optimization. The corresponding heat effects on DSC curves are always clearly detected as sharp peaks and practically not influenced by the factors mentioned previously. Even so, the lines in Fig. 13 to 15 fit all the experimental data reasonably well. Invariant reaction $\mathrm{M}_{1}$ is detected in alloys 18,21 , and $23, \mathrm{U}_{1}$ in alloy $2, \mathrm{E}_{1}$ in alloy $4, \mathrm{U}_{2}$ in alloys 5 and $6, \mathrm{U}_{3}$ in alloy $7, \mathrm{U}_{4}$ in alloy $8, \mathrm{U}_{5}$ 

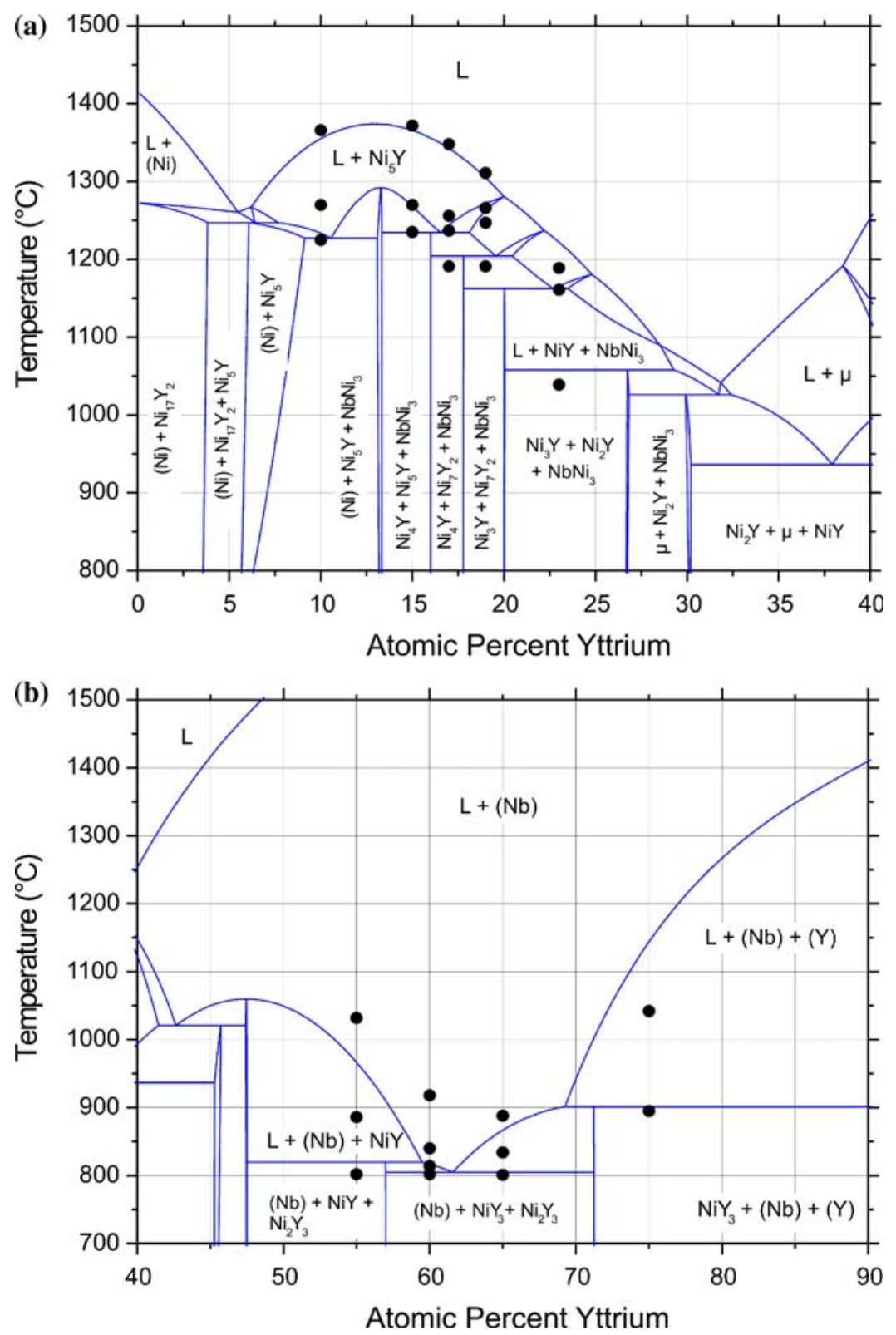

Fig. 14 Calculated temperature-composition section of the Nb-Ni-Y phase diagram at 5 at.\% Nb superimposed with experimental DSC data of this work. (a) Ni-rich part. (b) Y-rich part

in alloy $10, \mathrm{U}_{6}$ in alloys 13 and $14, \mathrm{U}_{7}$ in alloys 23 , and 24 , $\mathrm{E}_{2}$ in alloys $16,18,21,23,24, \mathrm{D}_{1}$ in alloy $31, \mathrm{D}_{2}$ in alloys $27,28,29$, and 30 , and $\mathrm{D}_{3}$ in alloy 29 .

Figure 13 shows two sections with the constant nickel content. At 40 at.\% Ni (Fig. 13a), the liquid miscibility gap extends from 4.4 to 42.8 at. $\%$ Y, whereas at 60 at. $\% \mathrm{Ni}$ (Fig. 13b) the liquid is homogeneous, in full agreement with experimental observations. The critical temperature of the miscibility gap at 40 at.\% $\mathrm{Ni}$ cannot be precisely calculated, the estimated value being $1922{ }^{\circ} \mathrm{C}$. The "ghost" thermal effects in alloys 21, 23, and 24 (Fig. 13a) correspond to the ternary eutectic $\mathrm{E}_{2}$, because at practical cooling rates the solidification path usually deviates from the equilibrium ones. Figure 14 shows the 5 at.\% Nb section, which looks rather similar to the Ni-Y binary phase diagram, while the $\mu$ phase and $(\mathrm{Nb})$ appear only at high $\mathrm{Y}$ contents. This observation is consistent with the immiscibility of $\mathrm{Nb}-\mathrm{Y}$ alloys and the degenerate character of four-phase equilibria near the monovariant eutectic, $\mathrm{L} \leftrightarrow \mathrm{Ni}_{2} \mathrm{Y}_{3}+\mathrm{NiY}_{3}$. From Fig. 15 (section at 10 at.\% Y) it is evident that ternary interactions in the $\mathrm{Nb}-\mathrm{Ni}-\mathrm{Y}$ liquid have the strongest influence on its thermodynamic properties in the region around 27 at.\% $\mathrm{Nb}$, while the liquid miscibility gap extends up to 33 at. $\% \mathrm{Nb}$. 


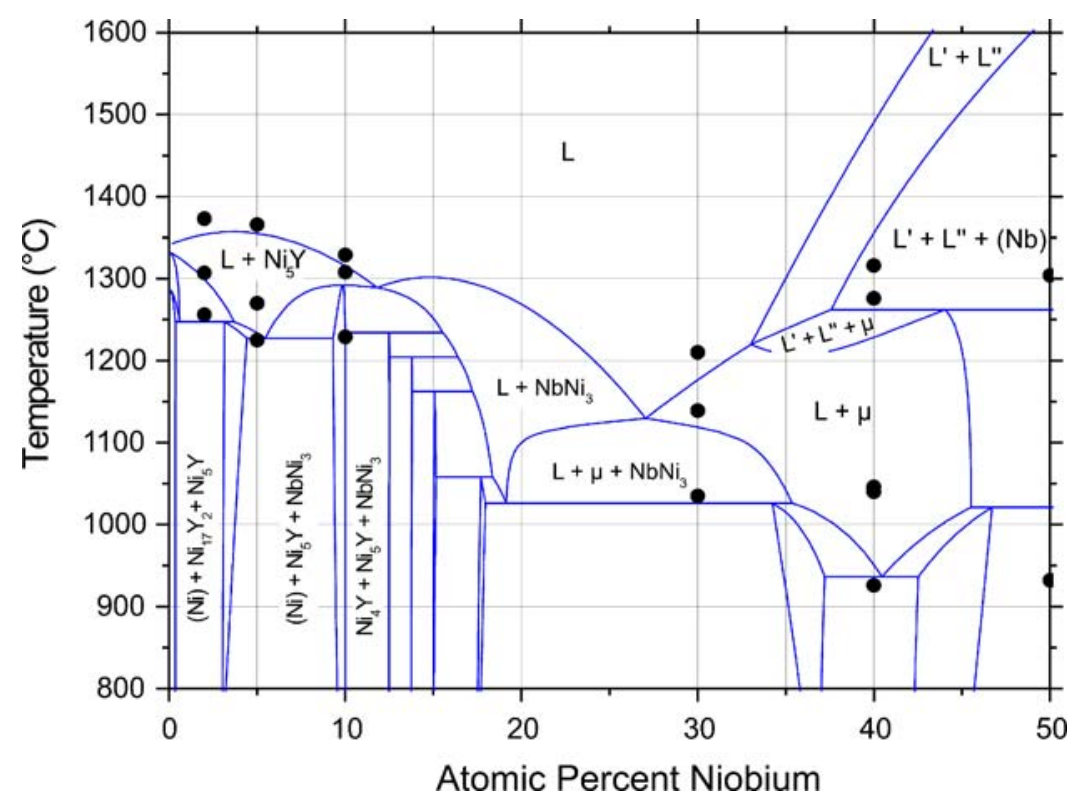

Fig. 15 Calculated temperature-composition section of the Nb-Ni-Y phase diagram at 10 at.\% Y superimposed with experimental DSC data of this work

\section{Summary}

Phase equilibria in the ternary $\mathrm{Nb}-\mathrm{Ni}-\mathrm{Y}$ system have been experimentally determined for the first time. Solidification microstructures have been analyzed using SEM and EDX, while thermal effects on heating and cooling have been detected by DSC. An isothermal section at $750{ }^{\circ} \mathrm{C}$, a projection of liquidus surface, and various temperature-composition sections have been constructed with the help of thermodynamic calculations by means of the CALPHAD method. The binary $\mathrm{Nb}-\mathrm{Ni}$ and $\mathrm{Ni}-\mathrm{Y}$ systems have been accepted from the literature, while the thermodynamic description of the $\mathrm{Nb}-\mathrm{Y}$ system has been obtained in the present work. The liquid phase as well as the terminal solid-solution phases, bcc, fcc, and cph have been described using a substitutional solution model and Muggianu interpolation of binary excess Gibbs energy. A composition-dependent ternary interaction parameter has been optimized for the liquid phase. The Nb-Ni-Y system is characterized by the wide range of liquid immiscibility (up to 60 at. $\% \mathrm{Ni}$ ), which originates from the $\mathrm{Nb}-\mathrm{Y}$ binary system. One monotectic, two eutectic, seven transitional, and three degenerated four-phase invariant equilibria exist in the system.

\section{Acknowledgment}

Technical support is gratefully acknowledged: M. Frey for sample preparation, H.G. Lindenkreuz for levitation experiments, B. Bartusch for DSC measurement, A. Ostwaldt for XRD, and S. Pichl for SEM analysis.

\section{References}

1. E.S. Park and D.H. Kim, Phase Separation and Enhancement of Plasticity in Cu-Zr-Al-Y Bulk Metallic Glasses, Acta Mater., 2006, 54, p 2597

2. A.A. Kündig, M. Ohnuma, D.H. Ping, T. Ohkubo, and K. Hono, In situ Formed Two-Phase Metallic Glass with Surface Fractal Microstructure, Acta Mater, 2004, 52, p 2441

3. B.J. Park, H.J. Chang, D.H. Kim, and W.T. Kim, In situ Formation of Two Amorphous Phases by Liquid Phase Separation in Y-Ti-Al-Co Alloy, Appl. Phys. Lett., 2004, 85, p 6353

4. N. Mattern, U. Kuehn, A. Gebert, T. Gemming, M. Zinkevich, H. Wendrock, and L. Schultz, Microstructure and Thermal Behavior of Two-Phase Amorphous Ni-Nb-Y Alloy, Scr. Mater., 2005, 53, p 271

5. N. Saunders and A.P. Miodownik, CALPHAD Calculation of Phase Diagrams, Pergamon Materials Series, 1998

6. SGTE Unary Database version 4.4, www.sgte.org

7. M. Hillert, The Compound Energy Formalism, J. Alloys Compd., 2001, 320, p 161

8. J.-M. Joubert, B. Sundman, and N. Dupin, Assessment of the Niobium-Nickel System, Calphad, 2004, 28, p 299

9. M. Hillert and M. Jarl, Model for Alloying Effects in Ferromagnetic Metals, Calphad, 1978, 2, p 227

10. J.O. Andersson, T. Helander, L. Höglund, P. Shi, and B. Sundman, Thermo-Calc \& DICTRA, Computational Tools for Materials Science, Calphad, 2002, 26, p 273

11. PANDAT - A Multi-component Phase Diagram Calculation Software, Computherm LLC, www.computherm.com

12. A. Bolcavage and U.R. Kattner, A Reassessment of the Calculated Ni-Nb Phase Diagram, J. Phase Equilib., 1996, 17, p 92

13. H. Chen and Y. Du, Refinement of the Thermodynamic Modeling of the Nb-Ni System, Calphad, 2006, 30, p 308

14. Z. Du and W. Zhang, Thermodynamic Assessment of the Ni-Y System, J. Alloys Compd., 1996, 245(1), p 164 
15. Z. Du and D. Lu, Thermodynamic Modeling of the Co-Ni-Y System, Intermetallics, 2005, 13, p 586

16. A. Palenzona and S. Cirafici, The Nb-Y (Niobium-Yttrium) System, J. Phase Equilib., 1991, 12, p 204

17. Y.M. Muggianu, M. Gambino, and J.P. Bros, Enthalpies of Formation of Liquid Alloys Bismuth-Gallium-Tin at
$723 \mathrm{~K}$ - Choice of an Analytical Representation of Integral and Partial Thermodynamic Functions of Mixing for This Ternary-System, J. Chim. Phys., 1975, 72, p 83

18. T. Gödecke, Ableitung des Kristallisationspfades in ternären Gusslegierungen, Z. Metallkd., 2001, 92, p 966, (in German) 